NBER WORKING PAPER SERIES

EAST ASIAN FINANCIAL AND ECONOMIC DEVELOPMENT

Randall Morck

Bernard Yeung

Working Paper 23845

http://www.nber.org/papers/w23845

\author{
NATIONAL BUREAU OF ECONOMIC RESEARCH \\ 1050 Massachusetts Avenue \\ Cambridge, MA 02138 \\ September 2017
}

This working paper is intended for the Handbook of Finance and Development. We are grateful to the editors, Thorsten Beck and Ross Levine for helpful comments and suggestions. The views expressed herein are those of the authors and do not necessarily reflect the views of the National Bureau of Economic Research.

NBER working papers are circulated for discussion and comment purposes. They have not been peer-reviewed or been subject to the review by the NBER Board of Directors that accompanies official NBER publications.

(C) 2017 by Randall Morck and Bernard Yeung. All rights reserved. Short sections of text, not to exceed two paragraphs, may be quoted without explicit permission provided that full credit, including (c) notice, is given to the source. 
East Asian Financial and Economic Development

Randall Morck and Bernard Yeung

NBER Working Paper No. 23845

September 2017

JEL No. G0,N25,N35,O1,O16,O53,P1,P11,P5

\begin{abstract}
$\underline{\text { ABSTRACT }}$
Japan, an isolated, backward country in the 1860s, industrialized rapidly to become a major industrial power by the 1930s. South Korea, among the world's poorest countries in the 1960s, joined the ranks of First World economies in little over a single generation. China now seems poised to follow a similar trajectory. All three cases highlight the importance of marginalized traditional elites, intensive early investment in education, a degree of economic openness, free markets, equity financing, early-stage coordination of firms in diverse industries via arrangements such as business groups, and political institutions capable of curbing the power of families grown wealthy in early-stage rapid development to make way for prosperity sustained by efficient resource allocation to high-productivity firms.
\end{abstract}

\author{
Randall Morck \\ Faculty of Business \\ University of Alberta \\ Edmonton, AB T6G 2R6 \\ CANADA \\ and NBER \\ randall.morck@ualberta.ca \\ Bernard Yeung \\ National University of Singapore \\ Mochtar Riady Building \\ 15 Kent Ridge Drive \\ BIZ 1, Level 6, \#6-19 \\ Singapore 119245 \\ bizdean@nus.edu.sg
}




\section{East Asian Financial and Economic Development}

A complete discussion of Asian development is too vast a topic for a single chapter. We focus on East Asia, and on that region's most successful large economies - Japan and South Korea. This omits fascinating developmental histories of successfully developed small economies - Hong Kong, Taiwan, and Singapore. We then focus on China, the region's largest economy and its ongoing rapid development.

In describing each country's ascent, our focus is on how it overcame (or in China's case, is overcoming) critical coordination problems that Rosenstein-Rodan (1943) shows to block the rapid rise of living standards in low-income countries. Of course, other things affect economic development as well, but the East Asian success stories we summarize suggest that they do so, in a large part at least, by contributing to the solution of these coordination problems. In both late $19^{\text {th }}$ century Japan and postwar Korea, functioning free market institutions, a degree of openness to the global economy, working stock markets, and passably good business group governance during critical high-growth periods are evident. In China, after a long series of politically and ideologically driven policies led to economic retrogression culminating in widespread poverty, a sequence of bold reforms raised the country into the ranks of middle-income economies. We argue that China's prior reforms leave it well-positioned to follow Japan and Korea into the ranks of high-income economies. In all three cases, this final stage was (or will be) closely accompanied by institutional changes or pressures to curb the power of elites grown wealthy in earlier stages of development.

\section{Financing Economic Development}

The development literature highlights many impediments blocking rapid economic growth. Critical impediments fell away in Japan, South Korea, and China, allowing rapid growth for substantial periods. Some features of these countries' histories are not transferable. For example, all three are relatively homogenous ethnically, which Easterly and Levin (1997) argue facilitates development. Other features they share are of ambiguous relevance. All share a Confucian-Buddhist religious tradition, which Rosenberg and Birdzell (1986) associate with rapid economic growth, but earlier studies link to backwardness (e.g. Weber 1915; Fairbank et al. 1960). All three also share a German legal origin (La 
Porta et al. 2008), a factor whose economic interpretation is problematic (see e.g. Beck et al. 2003). This section reviews key strands of the finance and development literature, highlighting studies relevant to the subsequent sections describing the ascents of Japan, South Korea and China. The literature is too large to cover thoroughly, so we focus on studies directly relevant to their financial development or to political, legal, or other institutional features relevant to their financial development.

\section{Basic institutions}

One very fundamental impediment to rapid financial development is traditional extractive elites - feudal landowners, regional warlords, court mandarins, and the like - who benefit from the status quo and protect their vested interests by blocking institutional reforms, even reforms as basic as universal education (Acemoglu et al. 2002; Rajan and Zingales 2003, 2004). China, Japan and South Korea were traditional extractive economies, and none was ever a European colony, either of settlement or extraction, though all three were briefly occupied by Western powers at the ends of major wars - Japan and South Korea after World War II and China after the Boxer Rebellion of 1899-1901. Japan's traditional nobility, disgraced by its inability to repel Admiral Perry's U.S. gunboats, was overthrown by reformers who comprehensively and selectively replaced Japan's discredited traditional institutions with institutions they perceived to be global best-practice. Japanese gunboats did much the same in Korea, which was a Japanese colony of extraction from 1910 to 1945, when its Japanese colonial extractive elite was expelled. Most colonial-era physical plant that survived the World War was devastated during the Korean War; however, intangible institutions such as the legal system remained. China's tumultuous $19^{\text {th }}$ and $20^{\text {th }}$-century history, culminating with Mao's purges of traditional elites and customs, likewise left China an institutional tabula rasa. Albeit at great cost to their citizens, all three countries had become institutional "blank slates", on which institutional reformers could draw anew.

Easterly and Levine (2016) show that former European settler colonies tend to have more growth enhancing institutions. Glaeser et al. (2004) argue that this empirical regularity turns on settlers' human capital (education); while Acemoglu et al. (2014) argue settlers brought a broad array of institutions relevant to financial development and other dimensions of development. Japan had unusually high levels of literacy before its comprehensive institutional reboot, which included measures to modernize education. Both South Korea in 1952 and China in 1978 had high illiteracy rates, but both undertook major educational reforms that rapidly lifted education levels before the advent of high growth. Intensive investment in education may well be important in providing abundant skilled labor to make 
foreign institutional imports operational. However, North Korea, which adopted the institutions of Stalin's Soviet Union, is also thought to have increased literacy rapidly after the Korean War, though official statistics are unavailable. North Korea's continued poverty in contrast to South Korea's ascent to the First World supports that argument of Acemoglu et al. $(2001$; 2014) that bad institutions can retard growth even if education levels are high.

\section{Efficient Capital Allocation for a Big Push}

Efficient allocation of capital is known to matter more than magnitude of investment to economic growth (King and Levine 1994; Levine 2005; Wurgler 2000); and inefficient capital allocation is attributed to barriers to external financing (King and Levine 1993ab; Rajan and Zingales 1998; Beck et al. 2000, 2004; Love 2003). Efficient capital allocation in high-income economies turns on technologically innovative upstart firms obtaining external capital. Because developing economies can grow rapidly using off the shelf technologies, capital allocation was long thought less important than the magnitude of investment at earlier stages of development (Harrod 1939; Domar 1946; Lewis 1954). However, this view misapprehends the complexity of the problem of economic development.

Capital allocation is thought to matter critically to rapid economic development because successful development entails constructing complex networks of interdependent firms (Rosenstein-Rodan 1943; Murphy et al. 1989). A high-income economy is a complex network of firms, each critically depending on the mere existence of uncounted other firms. Firms buy inputs from other firms, relying on the existence of multiple competing suppliers of every input to protect them from monopolistic pricing, shoddy quality, and hold-up problems of all sorts. Each such firm, in turn, relies on multiple competing firms to supply each of its inputs, as do their suppliers, their suppliers' suppliers, and so on. Every firm likewise depends on selling its output to multiple competing buyers, so that no monopsony buyer can drive down the price. These buyers likewise have buyers, as do their buyers. Every such firm relies on positive externalities from hosts of tangible and intangible public goods - highways, power grids, court systems, laws, accepted business practices, and the like - financed with general taxes made lucrative by the existence of the whole network.

New firms, typically unprofitable at first, even in developed economies, are especially vulnerable to bottlenecks in the network. The isolated state-of-the-art steel mill surrounded by a subsistence economy is economically unviable. Surrounded by a sparse network of other firms, its position can be 
little better. Monopolistic providers of raw materials, power, or transportation can "hold up" (Hart and Moore 1990) the steel firm by demanding monopolistic prices or side-payments, supplying low-quality goods or services, or regularly imposing costly delays. Monopsony buyers of steel can likewise "hold up" the steel mill to force down the price of the mill's products or applying other extortive tactics. Complete contracts in a perfectly efficient legal system let the parties involved commit to prices before making irreversible investments, but contracts always incomplete and contract enforcement is expensive and uncertain, and more so in lower-income economies (Djankov et al. 2003). Unless the steel mill has alternate suppliers and customers, it has no choice but to accept such treatment from other firms that do have alternative business partners or that have political influence sufficient to drive home their terms. Sparse network problems are still critical barriers to entry in low-income economies today (Weiss and Weber 2017).

The problem of capital allocation in a developing economy is thus the coordinated investment needed to construct an entire network of interdependent firms. Western European economies took centuries of trial and error to develop such networks. Rosenstein-Rodan (1943) argues that low-income economies can be transformed rapidly into high-income economies via the centrally coordinated establishment of this entire network, each component going into place and expanding to meet the needs of all the others. This necessitates firms in new sectors operating at inefficient economies of scales and/or refraining from exploiting market power for a time as the network forms. That is, individual firms must be run altruistically: not maximizing profits and perhaps eating losses deliberately for the good of the whole. Corporate governance directed towards firm value maximization precludes such behavior, and so impedes rapid economic development (Murphy et al. 1989).

Rosenstein-Rodan (1943) thus argues for a state-orchestrated Big Push, in which central planners lay out this entire ecosystem, pruning back firms that threaten other firms and spreading capital to where network as a whole currently needs growth. State-control, he argues, is essential because

"Existing institutions of international investment (floating of shares and loans) are inappropriate to the task of industrialisation of a whole area. They deal with too small units, and do not take advantage of external economies. Capital mostly goes to individual enterprises. There has never been a [private sector] scheme of planned industrialisation comprising a simultaneous planning of several complementary industries." 
Japan and South Korea both accomplished this transition to high-income economy status. Both encountered precisely the coordination problem Rosenstein-Rodan (1943) envisions. Both tried to solve it with state-directed development with, at best, very limited success. Easterly (2006) argues that the close business-government interdependencies intrinsic to a state-led Big Push so encourage political rent-seeking (corruption) as to make this growth strategy perversely detrimental to development. This is because the vast economic powers a state-run Big Push assigns to government officials make corrupting and controlling those officials the highest return investment option available to established firms positioned to benefit from hold up strategies.

In fact, both Japan and South Korea ultimately achieved successful transformations into high-income economies by freeing market forces to let large extraordinarily broadly diversified business groups of predominantly equity-financed firms coordinate the simultaneous rapid growth of multiple firms across multiple industries. The patriarch at each group's apex allocates that group's resources by command and control, coordinating investments in group firms across multiple different sectors. Competition among business groups for workers, consumers, capital, and exports limits the perverse incentives problems Easterly (2006) finds in state-run Big Push development programs. Rather, competing business groups, each orchestrating its version of Big Push coordination, can advance economy-level development. Indeed, in Japan and Korea, the largest groups comprised substantial shares of their national economies (Samsung member firms are about $12 \%$ of South Korea's GDP), so group-led Big Push coordinated expansions mobilized much of each nation's resources. During early industrialization, large business groups' objectives arguably align with rapid overall economic development. In this way, both countries ultimately relegated rapid development to a private-sector-led Big Push centrally planned at the business group level. Both countries then confronted the problem of dismantling these structures once their economic purpose was achieved.

China seems on a different course, but might merely be partway along what may turn out to be the same trajectory. The Communist Party of China (CPC) exercises strong central control over large networks of firms in multiple industries throughout the country. In theory, the CPC might orchestrate the state-directed Big Push Rosenstein-Rodan originally prescribed. The system seems organized to incentivize sub-government officials and SOE top managers to deliver tangible growth subject to a Party loyalty constraint, and SOE bank top executives to help them along. However, this development strategy seems vulnerable to Easterly's (2006) critique of state-led Big Push policies, which stressed their vulnerability to political rent-seeking (Krueger 1976). Corruption is a serious issue in China (Lü 2000) and 
its SOEs are less profitable than other firms, despite their access to subsidized capital and numerous regulatory privileges (Berkowitz et al. 2016). Such problems ultimately forced Japan and South Korea to liberate market forces, abandon dirigisme, and let privately-controlled business groups coordinate capital allocation. China may yet have to cross the bridge.

\section{Transition}

Once a functional network of competing firms is in place, an economy can draw abreast of other highincome economies. Sustaining growth from that point on requires ongoing productivity enhancement. In existing high-income economies, productivity growth arises from innovation, which is often disruptive (Fogel et al. 2008). Productivity growth is a process of creative destruction, wherein new upstart firms arise, destroying (partially at least) the value of old established firms (Schumpeter 1911). Efficient capital allocation - directing capital to upstart innovators and away from relatively lethargic established firms now becomes the central social purpose of the finance sector. The allocation of capital is thus central to sustaining rapid economic growth in both developing and developed economies (Levine and King 1993), though efficiency entails capitalizing the necessary network of interconnected firms in the former and capitalizing innovative upstart firms in the latter.

The owners of the established firms created in a successful Big Push rationally prefer the status quo, and corrupting government officials to erect regulatory barriers to entry that prevent creative destruction can become their highest return investment. Ascent into the ranks of high-income countries requires avoiding this Middle Income Trap, in which economic growth slows after an initial spurt of rapid development. Always developing, but never developed, entrapped economies' big business sectors are left the preserve of business dynasties descended from their first generation business elites, grown wealthy amid early-stage development, who use political influence to lock in a status quo favourable to them and their heirs (Olson 1963; Rajan and Zingales 2003, 2003a, Morck, Wolfenzon and Yeung, 2005). Haber $(1991,1997)$ posits this as an explanation for Latin America's slow growth.

Japan's early-stage business elite, arguably already cowed by the wartime military dictatorship, was displaced entirely by late 1940s reforms under US military occupation. Professionalized management at established firms and a burst of highly innovative entrants newly listed after World War II - Cassio, Honda, and Sony and many others - boosted Japanese productivity growth for decades thereafter. Korea's early stage business elite, tarred by high-profile corruption scandals arising out of their efforts to 
influence top politicians, is in the crosshairs of reformers. China is now a middle-income country, and the scions of its Communist era revolutionary leaders left now hold privileged positions. Communist princelings' rent-seeking might yet ensnare China in a Middle Income Trap that preserves their power and wealth. Or China may follow in Japan or Korea's footsteps, outlined below, by more comprehensively liberalizing to step past the snare. The Xi administration initiated an aggressive anticorruption campaign in Dec. 2012, which may further market development (Lin, Morck, Yeung, Zhao, 2016).

\section{Financial Systems and Stages of Development}

Japan and South Korea both relied primarily on stock markets during their high growth periods, and China's SOEs have tapped its stock markets. China is well positioned to rely on its stock markets to finance the growth of private sector firms. In both Japan and Korea, the equity financing provided risktolerant capital to business group controlling shareholders establishing new firms, or expanding existing firms, to complete needed supply chains. When bank financing was also used, it often made firms and business groups vulnerable to bankruptcies in economy-wide shocks, more common and severe in lower income economies (Morck et al. 2011). Highly leveraged firms and groups failed, those dependent more on equity financing survived episodes of market-wide volatility. This accords with Demirguc-Kunt and Maksimovic (2002), who find stock market development, but not banking system development, conducive to more firms using long-term external finance.

These observations need not contradict cross-country studies. Prior work (, e.g., Beck and Levine 2002, 2004; Levine 2002; Luintel et al. 2008) links overall financial development to growth, finds whether the financial system is bank or market-centered to be comparatively unimportant, especially after controlling for legal origin. Bank-centred and market-centered financial systems may solve different economic problems (Levine and Zervos 1998), and might even arise endogenously in response to an economy's economic conditions. ${ }^{1}$ Thus Japan (Morck and Nakamura 2005) and Germany (Fohlin 2005) both relied on stock market-centered financial systems to industrialize, but then relied on bankcentered financial systems to reconstruct their economies after World War II. ${ }^{2}$ The problems of initially

\footnotetext{
1 Banks and markets may ease different transaction costs (Levine 1997; Huybens and Smith 1999; Demirgüç-Kunt and Levine 2001). Boyd and Smith (1998) thus model credit and equity markets as complements.

2 Japanese banks in the $19^{\text {th }}$ and early $20^{\text {th }}$ century followed Scottish banking practice in requiring liquid collateral, such as inventories, and thus primarily financed trade rather than long-term investment. Japanese banks that did
} 
industrializing a low-income country and of rebuilding a war-devastated industrialized economy may require differently structured financial systems, and that of sustaining growth through creative destruction in a high-income economy may require yet another. Initial industrialization requires the coordinated roll-out of multiple firms in many different sectors, a task to which pyramidal business groups may be well suited, and is a highly uncertain proposition, for which more risk-tolerant equity financing may have advantages. In contrast, post-war reconstruction is primarily fixed capital investment to rebuild economic networks of firms whose viability is well-tested, tasks at which bank-centered financial systems might be better-suited (Jackson 2001, p. 184).

Once an economy reaches (or returns to) the technological frontier, a bank-centered financial system may prove less adept at financing ongoing disruptive innovations critical to growth through creative destruction. Banks in many developing economies are controlled by tycoons or powerful business families. Such banks might be ordered to decline loans to entrants whose creativity might destroy their existing capital (Morck and Yeung 2003; Rajan and Zingales 2003) and to lend energetically to other firms their controlling shareholder run during downturns, leaving the bank insolvent but apt to be bailed out by the state (Caprio and Levine 2002; Caprio, Lauven and Levine 2007; Lauven and Levine 2005). Such risk-shifting was evident in bank-financed business groups in both Japan and South Korea during their ascents. Similar episodes litter the financial histories of Latin America (Haber 2004, 2005; Maurer and Haber 2004; La Porta, Lopez-de-Silanes and Zamarripa 2003), Russia (Laeven (2001), and other economies (Morck, Yavuz and Yeung 2011).

Japan is rearranging its financial system towards reliance on equity markets to allocate capital (Franks et al. 2014). ${ }^{3}$ This is driven in part by banks' seeming reluctance to finance productivity boosting innovative upstarts, which often have few collateralizable assets and small odds of spectacular success. Information about new technologies is costly and financial markets' ability to mobilize the wisdom of crowds may trump the careful scrutiny of a banker, however well-informed (Allen and Gale 1999). Also, Gompers and Lerner (2004) show how the venture capital cycle, critical to financing disruptive innovation in the United States, depends on venture capital providers regularly bringing successful ventures via initial

finance long-term investment, generally controlled by the tycoons whose firms their financed, tended to fail in downturns (Morck and Nakamura 2005). Cameron et al. (1967) links sound banking systems to positive economic developments in Scotland and Japan. More competitive banking systems are generally associated with faster growth (Claessens et al. 2005).

3 No such shift is evident in Germany (Franks et al. 2015). 
public equity offerings to raise capital to fund a new cycle of start-ups. Finally, the dividends paid to shareholders can be cut if success fails to materialize; whereas debt-financing requires regular interest payments from the outset or the firm is bankrupted. This basic characteristic of equity seems advantageous to entrepreneurs raising external financing for uncertain innovative ventures. Japanese banks are also thought to be holding-up their borrowers, demanding they take out more and more costly loans and avoid risky investments (Weinstein and Yafeh 1998; Morck et al. 2000). Consistent with all of this, Brown et al. (2013) link stock market development to investment in innovation and credit market development, albeit less strongly, to fixed investment.

\section{How Japan Grew Rich}

Japan's "high growth" period, from roughly 1880 to the mid-1920s, lifted its initially very low living standards to European levels. ${ }^{4}$ The broad outline of Japan's growth trajectory features an era of unsuccessful state-directed economic development followed by an extended period of small government, free market economic policy, and stock-market centered corporate finance. This description jars with many popular accounts of the Japanese economy, and so requires elaboration.

\section{Isolation}

In 1543, Portuguese ships brought Christian priests and firearms and, in 1549, Saint Francis Xavier, who initiated an intense Jesuit mission to convert Japan. Spain's 1570 conquest of Manilla, abetted by converts, left Japanese Catholics' loyalty in doubt. In 1597, Chief Minister Toyotomi Hideyoshi ordered nine missionaries and seventeen converts crucified. In 1614, Hidetada, second Shogun of the Tokugawa Dynasty, expelled all missionaries for bringing disharmony and made Christianity a capital offense. Underground Christianity persisted nonetheless. A Christian uprising in 1637 provoked intensified efforts to stamp out residual foreign influence. In 1645, to restore harmony, Tokugawa Hidetada decreed the expulsion of all foreigners and a mandatory death penalty for foreigners entering Japan and Japanese returning from abroad.

For over two centuries thereafter, Japan was a world apart. Contact with the outside world was

\footnotetext{
${ }^{4}$ This section draws heavily on Morck and Nakamura $(2005,2007)$ throughout.
} 
restricted to one hermetically sealed Dutch trading post on a tiny artificial islet off Nagasaki. After a time, a trickle of foreign trade resumed and Western ideas - now called "Dutch Learning" - could be discussed, albeit very cautiously and in limited circles. A rigid and perversely inverted caste system left merchants socially inferior to warriors (samurai), peasants, and tradespeople. Japanese civilization, incomparably superior, had no use for foreigners' grotesque mechanical trinkets and treacherous notions, nor for foreigners' opprobrious preference for consorting with the exorable merchant caste.

\section{Shock Therapy}

Japan's penchant for executing shipwrecked sailors did not go unnoticed. In 1853 , to protect its whalers and pursue its Manifest Destiny, the United States dispatched one fourth of its navy (eight vessels, including four steam-powered "black ships"), commanded by Admiral Matthew Perry, to end Japan's isolation. Killing the foreigners proved difficult because their ships could change direction regardless of the wind and bombard Japanese ships and positions from far away. Tokugawa leyoshi despondently acquiesced to a treaty opening Japan to US citizens and trade. Other foreign countries then negotiated similar terms.

These agreements came to be called Unequal Treaties because they created "foreign concessions": enclaves, subject to foreign, rather than Japanese law, courts and police; but no analogous zone of Japanese jurisdiction adjacent New York or London. The foreigners pointed out that Western countries had never made being Japanese a capital offense, but the counterargument fell on deaf ears. The Unequal Treaties are still regarded as exemplifying foreigners' contempt for Japanese. However, the unequal treaties cut tariffs to very low levels and created foreign courts in these enclaves, in which business disputes could be settled. These gave Japan its first exposure to Western institutions.

Appalled by the craven Tokugawa, a band of young samurai overthrew the dynasty and seized power in the name of the Meiji Emperor in 1868. The leaders of this Meiji Restoration, once in power, quickly also realized how relatively weak Japan had become and concluded that the Japanese must "learn foreign ways [to] better resist foreigners" (Boot 2006).

To this end, the 1871-1872 Iwakura mission visited Europe and America to investigate foreign ways, and returned with a profound sense of Japan's backwardness. From the 1870s on, waves of young Japanese studied abroad, and all manner of Western experts were brought to Japan. Though local samurai 
rebellions erupted, opposition to reform faded. The Meiji rulers concluded that the comprehensive rebuilding of Japanese institutions according to global best practices was their only path forward. Japan adopted a Scottish banking system, British naval command, German legal code, American free press, Westminster bicameral parliament (its lower house elected by males with substantial property), universal compulsory public education (literacy in 1868 was roughly $40 \%$ for males and $15 \%$ for females, but rapidly rose into the $90 \%$ range for both), ${ }^{5}$ and diverse other Western institutional bits and pieces.

\section{A Failed State-led Big Push}

Japanese merchants were interested in trading with foreigners, but initially saw huge risk and scant profit in importing and operating foreign technology. The Meiji rulers wanted an economy capable of producing state-of the-art weaponry, and the craven merchant class was not up to the task. The government therefore established state-owned enterprises in every industry judged essential to upgrading the economy, each run by foreign-trained Japanese sometimes advised by foreign experts. Each state-owned enterprise was commanded to get the most modern technology available up and running as rapidly as possible.

A large stable of state-owned national champion firms was in place within a few years, but the cost was huge. The Meiji leadership understood that rapid industrialization would cost money, but envisioned state-owned mining firms' profits footing the bill for all other state-owned enterprises until they became profitable. This was not unreasonable. At the time, Japan had huge natural resource wealth, and stateowned coal, copper, gold, iron ore, and silver mining operations were all substantial (Morck and Nakamura 2017).

Unfortunately, all the state-owned enterprises (including the mining firms) continued losing increasing amounts of money. Each SOE had its orders, and the government had committed to provide the necessary funds. The SOEs thus had what Kornai (1986) calls soft budget constraints: market forces were not in play, so economic efficiency was at best subordinate to obeying orders. SOE losses mounted, and suppressing the final samurai mutiny (1877 to 1878) left the government's fiscal situation dire. By 1879 , Japan was in a full-fledged financial crisis. The first banks, largely capitalized by ex-samurai who accepted government bonds in compensation for the cancellation of their hereditary pensions, issued

\footnotetext{
5 See Kornicki (1998, p. 275) on the provenance and reliability of the early estimates and the rapid development of the education system.
} 
bank notes unreservedly to keep up their lending (Tang 2013). Inflation soared; the government was broke, the currency collapsed, and its sovereign debt was unsalable.

As a last resort, with economic and state collapse looming and no other option available, the Japanese government resigned itself to a liberal free market economy. Finance Minister Matsusaka Masayoshi created the Bank of Japan with a monopoly on banknote printing, rewrote banking regulations to allow the formation of a new generation of stable banks, and slashed subsidies to state-owned enterprises, demanding financial reports from each. Using the state-owned enterprises' balance sheets and income statements to highlight the costs to date and ongoing maintenance costs of each state-owned enterprise, Matsusaka succeeded in imposing hard budget constraints and mobilizing widespread political and public support for a mass privatization. In the world's first mass privatization, he auctioned off almost all the SOEs to private owners in the 1880s. Thereafter, the government focused on building infrastructure and a handful of remaining state-owned enterprises with military importance. ${ }^{6}$

\section{A Successful Private-sector Big Push}

Burnt by the 1879 financial crisis, a generation of Japanese leaders embraced Victorian liberalism, free markets, and minimal government (Morikawa 1992; Morck and Nakamura 2007). The state would henceforth finance courts, schools, and national defense. The yen went on the gold standard, and Japanese sovereign debt discounts narrowed (Sussman and Yafeh 2000). There would be no more huge subsidies to business, no more industrial policies subsidizing national champion firms, and no more state-sponsored national building (Miyajima 2004). For the next four decades, market forces would allocate resources. These decades were also relatively, though not entirely, corruption free - perhaps because officials were both relatively well paid and markedly less worth corrupting under laissez-faire.

The mass privatization reallocated capital assets and talented employees to old merchant families, such as the Mitsui (silk merchants) and Sumitomo (copper mine owners), as well as new entrepreneurs who would end up running huge business empires - Mitsubishi, Nissan, and others. These could do what the government could not: each initially used one or more mining firms as cash cows, recycling mining earnings (grown substantial under private-sector management) into revitalizing industrial SOEs that

\footnotetext{
6 A few subsidies persisted. A Mistubishi company continued receiving subsidies for carrying government mail. Politicians condemned Mitsubishi for tunneling these subsidies to finance investment in other businesses. For a list of major firms privatized, prices, and buyers see Morck and Nakamura (2007).
} 
ended up in their hands or into buying assets and hiring employees away from floundering ex-SOEs (Morck and Nakamura 2017). ${ }^{7}$ As these business empires grew, they channeled the earnings of their mines and other firms grown profitable into capitalizing yet more new firms to provide inputs, services, or uses for excess outputs needed by existing group firms. These business groups were dubbed zaibatsu (財閥, lit. financial cliques).

A nationwide banking system developed from the 1880s on (Mitchener and Ohnuki 2009), and most such business groups contained a bank. However, group banks did not lend to finance new group firms capital spending or operating costs in most cases. Rather, most group banks seem to have adhered to Scottish banking practices (notably, the real bills doctrine), requiring that loans be backed by liquid collateral, preferably inventories. Bank loans thus facilitated transactions and zaibatsu expansion was ultimately largely equity financed, especially in the early $20^{\text {th }}$ century. ${ }^{8}$

The exceptions to this rule are of special interest. A few zaibatsu used their banks to finance capital investment by their other member firms. Called "organ banks" (Kato 1957), these group industrial development banks are associated with financial instability. The most prominent case was the Suzuki zaibatsu, whose Taiwan Bank collapsed in 1923 when a major earthquake caused a sharp recession, initiating a chain reaction of bankruptcies that destroyed the entire highly leveraged zaibatsu. Other organ banks similarly disappeared in consolidations forced by 1920s banking reforms (Okazaki and Sawada 2007). Banks controlled by business tycoons or families who also control industrial firms are associated with capital misallocation in recent decades (Morck, Yavuz and Yeung 2011). This may be because their controlling shareholders can tunnel income away from their bank to bail out their industrial firms, confident that the government would bail out their banks (La Porta et al. 2003, Lauven and Levine 2009). ${ }^{9}$

Economy-wide diversification might offer sufficient risk reduction to justify high leverage in diversified group firms in high-income economies (Hoshi et al. 1990, 1991; though see also Morck and Tian 2017), However, developing economies typically have much higher market-wide risk (Morck et al. 2000), so

7 On the importance of mining earnings to each nascent business group, see Morck and Nakamura (2017).

${ }^{8}$ One exception, the Sumitomo zaibatsu, refrained from doing so until the 1930s. Earnings from its copper mines sufficed to finance expansions and new subsidiaries until that point.

9 Johnson et al. (2000) call the transfer of assets or liabilities at non-market prices between separately listed member firms of a business group to enhance the wealth of its ultimate controlling shareholder "tunnelling. Tunnelling is regarded as a corporate governance problem by the losing firm in the transaction. 
cross-industry risk-sharing provides creditors limited protection from bankruptcy risk in their more frequent and severe economy-wide downturns. In contrast, shareholders must accept systematic risk without recourse to bankruptcy protection.

As industrialization accelerated, the profits of their mines and other existing firms became insufficient to finance needed group expansions, so the zaibatsu tapped Japan's stock markets (Rosovsky 1961). Stock exchanges, founded in Tokyo and Osaka in 1878, now became important sources of start-up capital (Franks et al. 2014). The late $19^{\text {th }}$ and especially the early $20^{\text {th }}$ century saw massive equity issuances, as existing firms used the proceeds of equity issues to capitalize growing ranks of listed subsidiaries (Miyajima 2004). These equity issues reshaped the business groups into pyramids: the tycoon or business family directly controlling one (or a few) listed or unlisted firms, each of which controlled a set of listed firms, which each controlled yet other listed firms, and so on. Pyramidal structures of multiple tiers of listed firms controlling listed firms controlling listed firms, also prominent in other late industrializing countries in the West, became the defining characteristic of Japan's zaibatsu business groups.

Most of these pyramidal business groups were ultimately controlled by business families, but some were run by entrepreneurs and capped by widely held apex firms. For example, Nissan zaibatsu was a pyramidal group with a widely held firm at its apex. Lower tier firms' shareholders had to accept their firms being run to benefit other firms in the group. To retain control, Nissan's tycoon needed only to retain the support of shareholders in the apex holding company by maximizing its share shareholder value, subsidiaries in lower tiers of the Nissan pyramidal business group likewise had to accept their fates.

Morck and Nakamura (2007) argue that Japan's great zaibatsu were the private-sector mechanisms for coordinating the development of multiple sectors of the economy that Rosenstein-Rodan asserted do not exist. By the turn of the $20^{\text {th }}$ century, each major zaibatsu had at least one member firm in every significant sector. Because all the firms in a zaibatsu were under the unified control of its tycoon or business family, its member firms could be made to forego profits and even to lose money to benefit the group as a whole. This "full set" diversification was necessary so that no group firm had to depend on a non-group firm, which might "hold-up" the group firm by exerting market power, providing low quality inputs, or otherwise behaving opportunistically. With multiple firms along all intersecting product chains under common control, hold-up problems could be eliminated (Grossman and Hart 1986). 
The zaibatsu firms enthusiastically imported foreign technology (Goto 1982). Zaibatsu corporate governance was at the business group level, and entailed a centralized managerial control and coordination, whereby the apex firm collected the profits of the entire business group and then strategically financed expansions of existing group firms and the creation of new firms embodying new technologies deemed important to the group as a whole (Aoki 1988, p 223). This could force individual firms to forego profit maximization by forsaking hold-up opportunities, so the group as a whole could transcend market imperfections that would render freestanding firms unviable (Rosenstein-Rodan 1943; Khanna and Yafeh 2007). Miyajima (2004) highlights how the controlling shareholder monitored and controlled the capital investment of zaibatsu member firms in multiple industries. Hasegawa (1938) describes a centralized budgeting process applied across all member firms in the Nissan zaibatsu. Nissan's founder describes reallocating profitable firms' earnings to subsidize unprofitable, but necessary, firms and new firms necessary to the nation and the group's long term prospects (Morck and Nakamura 2007, p 583). Mitsubishi member firms remitted their entire earnings to the apex firm for reallocation to where the group needed higher investment, much as Soviet state-owned enterprises remitted their entire earnings to the central planners in Moscow for reallocation across the economy in accordance with the central plan. In general, the zaibatsu used earnings from profitable firms to finance investment in new or unprofitable, but necessary, firms (Almeida and Wolfenzon 2006). Morikawa (1992, p. 105) observes that zaibatsu member firms' managers recognized that an individual firm's fortune sometimes had to be sacrificed for the group's "national" objectives (Morikawa 1992, p. 105).

Group firms were not always needed to provide inputs or buy outputs. Sufficient numbers of competing independent firms arose in some sectors. Most importantly, the Unequal Treaties had forced Japan open to foreign trade, so imports and exports could fill in missing pieces of the economic network where transportation costs were not prohibitive. In particular, Japanese firms with insufficient domestic markets attain efficient economies of scale by exporting. By the 1910s, Japanese exports were everywhere (Meissner and Tang 2017), and Japanese supply helped sustain the Allies in World War I. This dovetails with Trindade's (2005) argument that trade openness can mitigate coordination costs in Big Push industrializations.

\section{Asia's First High-income Economy}

Japan's high growth period, from the 1880s to the 1920s, saw the country rise into the ranks of developed economies. Despite damage to its Kanto plain industrial heartland in a severe 1923 
earthquake, Japan's economy attained an industrial composition not greatly different from many Western economies by the end of the 1920s: natural resources were greatly diminished; manufacturing and services were greatly expanded. While Japan's 1930s per capita GDP still trailed that in the richest Western economies, Japanese living standards were on par with those in much of Europe.

Japan sought international recognition as an industrial power in the interwar era (Kajima 1967). Its 1895 defeat of the Qing navy and colonization of Taiwan, 1905 defeat of the Russian navy, 1910 colonization of Korea, and important role in supplying the Allied Powers in World War I made Japan a player in Great Power politics. Many Japanese took pride in what other Asians saw as an increasingly aggressive expansionism. Japanese students resented racism they experienced while abroad. When the post-WW I Versailles Treaty Commission, chaired by the Progressive US President Woodrow Wilson, rejected a Japanese proposal for a racial equality clause, liberal Japanese were justifiably dismayed. ${ }^{10}$ Nationalists began reminding people why Japan had decided to "learn foreign ways" in the first place.

As the Great Depression devastated the Western economies, intellectuals and pundits everywhere proclaimed that capitalism and democracy had run their course. Reischauer (1988, p. 305) describes "widespread condemnation of the zaibatsu, particularly by the supporters of the military, as elements of Western decadence in Japanese society, corrupters of the parliamentary system, and money grubbing betrayers of Japan's imperial destiny" in the interwar decades. The zaibatsu controlling shareholders, in particular, were berated for their myopia in putting their short-term profits ahead of the country's longrun greatness. As the global economic collapse deepened, Japanese nationalists remembered, or imagined they remembered, a purer and nobler samurai warrior spirit. The military was constitutionally well placed to exploit this sentiment.

\section{Military Dictatorship}

Japan's constitution made the military High Command, like the civilian government, subject only to the Emperor, who was expected to be a mere figurehead. This left the High Command legally free of civilian oversight. The Prime Minister could neither command nor discipline Japan's admirals and generals; and when secret societies of sincere officers began assassinating elected politicians, the government and courts were impotent. Soon, only military officers accepted high government positions and, by the mid-

\footnotetext{
${ }^{10}$ Wilson promoted eugenics and imposed racial segregation across the US federal civil service (Goldberg 2008 ).
} 
1930s, Japan was effectively a military dictatorship. Cabals of sincere zealots within the army orchestrated Japan's attacks on China, East Asia and Hawaii, with sometimes apparently secretly appalled civilian government officials rushing to look like they were in charge (Buruma 2003).

The military had no patience for market forces. The wartime economy was a command and control system (Okazaki 1994; Noguchi 1998). The military assigned each plant production quotas and controlled agency costs by militarizing human resources management. The role of the zaibatsu families in the wartime economy is controversial. Seemingly, they cheered the war effort on, but the military had effectively marginalized them and cut their income streams by severely curtailing dividends to provide more retained earnings to finance the war effort.

\section{American Occupation}

At the end of WWII, Japan in 1945 was in ruins. US firebombing had incinerated major cities and industrial plants, and the nuclear bombing of Hiroshima and Nagasaki had shattered the military's plans to deter occupation by promising a protracted guerrilla war. Japan surrendered unconditionally and an American military government under General Douglas McArthur ruled the country from 1945 to 1952.

Economic policy under the US occupation was largely delegated to New Dealers weaned on the extensive state intervention in the US economy characteristic of successive Roosevelt Administrations. New Deal economists in the US, led by Adolf Berle and Gardiner Means (1933), had sought to rebuild popular trust in the U.S. economy with reforms attacking big businesses. Key to this strategy was a series of reforms aimed at dismantling the pyramidal business groups, quite similar to Japan's zaibatsu, controlled by America's "robber barons". These reforms (Kandel et al. 2017) included escalating taxes on inter-corporate dividends, a prohibition on large scale business groups in public utilities, reforms to sever ties between large banks and industrial firms they previously controlled, and reforms subjecting companies whose assets are shares in other companies to regulation as mutual funds. While no single reform was critical, the ensemble effectively rid the US of pyramidal business groups by 1950 .

Reassigned to Japan, New Deal economists saw similar reforms rebuilding confidence in capitalism and democracy in Japan. Moreover, reforms would be easier because Japan was under a military occupation. Nuanced regulatory reforms were unnecessary: the occupation government simply seized and reallocated both the zaibatsu families' shares and the inter-corporate equity blocks that held their 
pyramidal groups together. The zaibatsu families, compensated with government bonds that quickly lost most of their value amid high post-war inflation, left the stage.

When the US withdrew in 1952, it left a post-New Deal US corporate governance system in place (Morck and Nakamura 2005; Franks et al. 2014). Most Japanese corporations had widely held share ownership and were run by salaried professional managers (sarariman). After stock markets reopened, a wave of IPOs unrivaled since the high growth period capitalized new corporations - Honda, Sony, Sanyo, and many others - that would become global leaders in subsequent decades (Mehrotra et al. 2011).

\section{Japan Resumes its Place}

The major task the Japanese government and financial system had before them was not economic development, but the reconstruction of a war-devastated developed economy. For this, bank financing was preferred, for reconstructed property, plant and equipment served well as collateral and proven pre-war managers and skilled employees awaited work.

Unpropitious developments in Japanese equity markets reinforced this tilt towards debt financing. The dispersed share ownership structures the American regime created left Japanese firms vulnerable to hostile takeover and greenmail threats. ${ }^{11}$ To halt this, Japanese banks organized groups of firms into mutual defense organizations called keiretsu (Sheard 1991, 1994). To form a keiretsu, a group of firms (often former member firms of the same pre-war zaibatsu) acquired blocks of stock, typically two or three percent stakes, in each other. Each firms' income statement could be left unaffected by issuing and acquiring shares to balance its increased dividend expenses against its increased dividend income. Thus, in a keiretsu of 30 firms, each taking two percent stakes in each other, each firm in the group would end up $60 \%$ owned by the other keiretsu member firms collectively, but with no single firm having a dominant block in any other. The organizing bank's equity block, though capped after 1953, was often the largest among these. Every keiretsu member firm remained fully protected against hostile takeovers because the keiretsu member firms pledged never to sell their "stable" shareholdings in each other. ${ }^{12}$

The system was remarkably effective. When the American raider T. Boone Pickens sought to take over

\footnotetext{
${ }^{11}$ Greenmail refers to a target firm buying back all of its shares that a hostile bidder has purchased, typically at a high price that provides the hostile bidder a side payment for abandoning the takeover.

${ }^{12}$ Franks et al. (2014) note that all this occurred under a regime of strong de jure shareholder rights, highlighting the de facto inadequacies of such measures.
} 
the seemingly widely held Koito Auto Parts Company in 1987, he found he could not (Morck and Nakamura 1999). Nineteen other Japanese firms, each with a small stake, collectively owned a majority of Koito stock and would not tender, nor even acquiesce to Pickens, the firm's largest shareholder by a huge margin, having a single representative on Koito's board. Pickens had to walk away. Japanese managers were thus insulated from pressure to increase shareholder value. Hostile takeover and greenmail threats had ceased, but so had initial public offerings. Firms turned to bank-loans and bankfinanced bonds to fund reconstruction. This was facilitated by keiretsu member firms propping each other up to reduce every member firm's overall bankruptcy risk and cost of debt (Hoshi et al. 1992). The next decades, from the mid-1960s to the 1980s saw the full reconstruction of the economy and Japan's emergence, or rather, its re-emergence, as a major developed economy.

From the 1950 s to the 1980 s, Japan's economy grew rapidly, and the country resumed its place among the world's richest economies. This was the era of Japan's global pre-eminence as an alternative economic model characterized by bank-centered financing and state coordinated economic growth (Morris-Suzuki and Seiyama, eds. 1989). Japan's keiretsu member firms were good financial performers in the 1960s and bank oversight of their corporate governance was lauded (Aoki and Patrick 1994; Kaplan and Minton 1994; Li and Li 1996). Bank corporate governance oversight and intra-keiretsu bailouts (Morck and Nakamura 1999) made high leverage to finance capital investment projects seem viable for keiretsu member firms (Hoshi et al. 1990, 1991). With the post-war era of low-risk high return reconstruction drawing to a close, Johnson (1982) credits Japanese bankers and bureaucrats, especially in the Ministry of International Trade and Investment (MITI), for competently orchestrating Japan's rise by circumventing market forces. Less restrained Japan-experts began lauding the country as a new alternative economic model, superior to capitalism (critiqued by Beason and Patterson 2004).

Such claims now seem inflated at best. Like industrial policy bureaucracies elsewhere, MITI "picked losers" (Beason and Weinstein 1996). Nogochi (1998) links the post-war system of bureaucratic planning, ineffective shareholder rights, and rigidly hierarchical human resources management to the wartime military economic system. Nonetheless, Japan recovered smartly under this system. Perhaps oversight by bankers and bureaucrats is appropriate to reconstructing a war-devastated developed economy. ${ }^{13}$

\footnotetext{
${ }^{13}$ Germany also initially industrialized under a $19^{\text {th }}$ century equity market dominated financial system, but recovered rapidly from wartime economic devastation under a bank-led financial system (Fohlin 2005).
} 
In the late 1980s, capital continued flowing into Japanese businesses and a bubble economy developed (Uchida and Nakagawa 2007). Lacking viable internal investment projects, Japanese firms poured borrowed money into real estate speculation and foreign acquisitions. The bubble burst at the end of the 1980s, triggering a financial crisis. Firms whose banks more heavily involved in real estate loans were especially adversely affected (Gan 2007). "Zombie firms," keiretsu member firms not quite bankrupt but insulated from takeovers, staggered along (Hoshi and Kashyap 2004, Peek and Rosengren 2005). A long era much slower growth ensued.

While these years have been referred to as Japan's lost decades, unemployment and inflation were low and most people got on with their lives. Japan had resumed its position on the technological frontier and, deprived of easy growth through catching up, now began to retool large sections of its economy grown unaccustomed to innovation and the economic instability associated with creative destruction. Japan's financial system is reverting to its pre-war market-centred form (Franks et al. 2014). Initial public offerings resumed (Katsuna 2004; Katsuna et al. 2009), though bankers feature prominently on many newly listed firms' boards (Takahashi 2015). Corporate takeovers resumed, but new takeover defenses swiftly followed - notably the 2005 advent of the poison pill (Arikawa and Mitsusada 2011), a US antitakeover defense. However, the power of banks remains prominent. For example, Japanese takeover look quite different from those in other countries. In the United States, takeover targets' share prices rise and bidders share process can move either up or down (Morck et al. 1990). In Japan, bidder firms share prices rise on news that they are launching takeovers (Kang et al. 2000), and target firms' share prices fall - apparently because mergers are often bank-orchestrated bailouts of a financially distressed bidder by a more financially solvent target tied up in cross-holdings (Mehrotra et al. 2011). Increasing numbers of Japanese firms are also turning to season equity issues to raise capital. Elsewhere, firm's share prices drop on news of seasoned equity announcements because investors presume the firm would not issue more shares unless its shares were overvalued (Myers and Majluf 1984). But Japanese shares rise on seasoned equity issue announcements, probably because equity financing reduces their dependence on their banks (Cooney et al. 2003). The use of executive stock options also boosts share prices (Hideaki et al. 2005), perhaps because it incentivizes CEOs to attend less to banks and more to shareholders.

Nonetheless, many large Japanese firms, especially those in keiretsu, remain deeply tied to and dependent on their banks (Yasuda 2007; Amiti and Weinstein 2011). Bankers serve on many firms' boards (Kaplan and Minton 199x; Morck and Nakamura 1999) and banks often hold large equity blocks 
in the firms they lend to (Hodder and Tschoegel 1985; Prowse 1990; Flath 1993). Such bank connections are associated with depressed share valuations (Morck et al. 2000) and capital misallocation (Hoshi and Kashyap 2004; Peek and Rosengreen 2005). Firms with stronger bank ties borrow more, pay higher interest rates, and post lower profits (Weinstein and Yafeh 1998), suggesting their banks have hold-up power (Rajan 1992). Hanazaki and Horiuchi $(2000,2001)$ argue that this system compromised the quality of bank lending as well. Nonetheless, a broad change of direction towards a market-centred financial system akin to that in the United States is increasingly evident (Aoki et al. 2007; Franks et al. 2014).

\section{How South Korea Grew Rich ${ }^{14}$}

Korea during its Goryeo Dynasty (918-1392 A.D.) was an economically sophisticated realm that traded with Arabs, Japanese, Chinese, and Manchurians (Ho 2014). The subsequent Joseon Dynasty (1392-1897 A.D.) shut out the world and Korea became known as the "hermit kingdom." Christian missionaries, preaching obedience to Rome, rather than the dynasty, grew increasingly pernicious and in 1758 the dynasty outlawed Christianity. The religion was relegalized in 1785 , but state-sanctioned pogroms killed large numbers of Christians in 1801 and again 1866.

The dynasty's foreign policy of sadae (lit. serve the great) entailed acquiescing to tributary status under China and shutting out the rest of the world. This ended when Japan's Captain Inoue Yoshika, having learned his trade from Admiral Perry, steamed his Western-armed Japanese gunboats into Korean ports. Emulating its treatment by the United States, Japan forced Korea to sign the "unequal treaty" of 1876 severing it tributary obligations to China, opening three ports to Japanese merchants, and granting Japanese trading enclaves extraterritorial legal status. The Western powers followed suit, and a brief period of modernizing reforms followed. However, the Korean Empire became a Japanese protectorate in 1905 and a Japanese colony in 1910.

\section{A Blank Slate}

Japanese colonial rule is generally remembered for its ruthless destruction of Korean institutions: the overthrow of Korea's traditional aristocracy of Confucian sophocrats and landowners and the

\footnotetext{
${ }^{14}$ This section draws heavily on Lim (2000, 2012), Lim and Hahm (2006), and Lim and Morck (2017).
} 
suppressing of its rigid caste system, which was similar to that of Tokugawa Japan. Although Kohli (1999) and Shin and Robinson (2000) find some positive contributions in Japanese colonialism, such views are controversial and revisionist (Haggard et al. 1997). The Japanese are roundly condemned for treating Koreans deplorably (Cummings 2005, p. 135). An 1890s visitor describes "a wilderness of demons, rag, dogs, unburied dead, vermin, squalor." (James Scarth Gale, quoted in Cummings 2005, p. 136). When colonial rule ended in 1945, 78\% of Koreans were illiterate. However, ill intentions need not end badly. Acemoglu et al. (2002) argue that stronger traditional institutions can impede economic development by helping entrench elites protect their vested interests. A point of general agreement is that Korea's traditional institutions and elites were shattered by colonial rule, and Woo (1991) argues that the not having a traditional elite greatly contributed to Korea's ultimate success

The colonial era ended in 1945 with the peninsula's partition into a Soviet-controlled northern sector and a US-controlled southern sector. In 1948, the Democratic People's Republic of Korea (North Korea) and Republic of Korea (South Korea) gained independence. After a communist insurrection in South Korea, North Korea's army invaded in 1950, devastating the country as South Korea's military retreated to the southern extreme of the peninsula. A US-led counter-offensive pushed fighting back up to near the Chinese frontier, whereupon the Chinese army responded pushing the South Koreans and Americans back down to the southern tip. In 1953, a renewed US-led offensive pushed the front back to roughly where it had been in 1950 . Thus, armies trampled most of the peninsula multiple times.

For the second time, existing institutions and elites were destroyed. By 1953, few colonial era vested interests retained any influence and little existing capital remained to defend in any event. South Korea, perhaps more than any other country in modern history, was a "blank slate" on which new institutions could be designed.

\section{Syngman Rhee and Crony Capitalism}

South Korea's first president, Syngman Rhee, was a student of Princeton professor (and later US President) Woodrow Wilson. Rhee valued education and rolled out universal compulsory public education (Seth 2002). His core development policy channeled a massive flow of US foreign aid into subsidizing businesses protected by an import substitution program run by people he trusted (Haggard et al. 1991). Many of these businesses were remnants of Japanese-owned businesses he had seized (without compensation) and privatized at subsidized prices to favored buyers (Lim 1999, 2003). 
Privatized banks often went to the buyers of privatized industrial firms, who used their banks to finance their purchases of their other firms (Cho and Kim 1997; Lim 2003).

Rhee's education program raised literacy markedly (Azariadis and Allan 1990), but his crony capitalism primarily enriched his family and his cronies. South Korea remained among the poorest countries in the world. Virtually any country in sub-Saharan Africa looked to have better odds for rapid development and dismayed US officials disparaged South Korea as a "foreign aid sinkhole" (Chapin 1969), though Campbell and Tullock (1958) blame inept and naïve US economic advisors. Rhee was well-educated about the workings of US government, and kept large-scale US aid flowing with few interruptions through successive scandals and financial crises. The dismayed US officials were also right about its efficacy. By 1959, South Korea's living standards were no higher than in 1945 and North Korea seemed the richer of the two countries. The state-owned Korea Development Bank was plagued by nonperforming industrial development loans; political cronies used their banks as cash cows to fund their financially shaky other firms. Rhee seemed to be leading the country towards penury, and his attempt to steal an election provided an excuse for ousting him in 1960 (Kim and Koh 1972).

\section{Park Chung-hee and the Developmental State}

A democratic election brought Chang John Myun to power on a platform of prosecuting corrupt business leaders, cutting military spending and professionalizing the civil service (Han 1974). Rhee's terrified ex-cronies readily acquiesced to General Park Chung-hee seizing power in 1961 and holding it until he was assassinated in a 1979 coup. Park, though a son of poor peasants, had studied at the Japanese Military Academy in Manchukuo (Japanese-ruled Manchuria), then another Japanese colonial possession, and later at the elite Tokyo Military Academy. He was consequently both aware of pre-war Japanese institutions.

Park earned the gratitude of Rhee's cronies by bailing out some of their businesses (though he nationalized their banks), and their fear by threatening to restart Chang's prosecutions (Lim 2002). He earned the respect of the military by increasing its budget. He earned continued US aid by restoring a veneer of democracy and cracking down hard on all further corruption. Park followed through with Chang's initiative to professionalize the civil service. Trained to look down on merchants, he viewed any officers or officials who consorted with them as unworthy; and his successive administrations are generally regarded as relatively, though certainly not totally, corruption-free. 
Park's most pressing challenge was retaining the continued support of the military by bringing South Korea up to economic and military parity with North Korea. Some of his initiatives were unambiguously successful. For example, to improve the health of military conscripts, the regime brought treated water to the villages (Park 2009). Others were less well-considered. His first effort to spur the economy, an inflationary import-substitution program, culminated in a financial crisis and a condition-laden US bailout that greatly limited Park's freedom of action (Haggard et al. 1991; Lim 2003).

His subsequent interventions in the economy became more narrowly focused - in the words of Amsden (1991), more "disciplined." His second effort centered on earning foreign exchange, needed for imports important to the military (Lim 2003). Meeting regularly with exporting firms' owners, Park tracked individual firms' exports, regularly rewarding successful exporting firms with subsidies (notably, stateguarantees for their foreign borrowings) and their controlling owners with medals (Haggard et al. 1991; Kim 2004). Thus, although protected from imports, Korean firms had to confront global market forces to export. However, his guarantees of firms' foreign borrowings triggered another financial crisis in 1969 when the inevitable moral hazard problems materialized. Park held to his guarantees of the overleveraged exporter firms' foreign debt and submitted to IMF conditions for a government bailout, but left other firms on their own. The crisis reverberated through the domestic economy as financially stressed firms borrowed at escalating rates from shadow banks, then called the curb loan sector. In 1972, Park ended the crisis by declaring a three-year debt moratorium, after which curb loan interest rates were to reset to $16.2 \%$, payable over 5 years, though market rates had been near 40\% (Lim 2003). This was essentially a state-enforced transfer from curb market lenders to borrowers.

Concerned with American's failure to defend South Vietnam and the unrelenting threat from North Korea, Park then launched his Heavy and Chemical Industries $(\mathrm{HCl})$ drive, a massive effort to subsidize domestic firms important to the military. Chosen firms received subsidized loans directly from the state or through state-owned banks. However, Park now worried about firms with excessive debt, and so encouraged firms to issue equity. The Korea Stock Exchange, founded in 1956, had previously played a minor economic role. The 1970s saw a burst of equity financed capitalizations of new firms and expansions of existing firms in pyramidal business group structures essentially identical to Japan's prewar zaibatsu business groups. These structures, called chaebol (재벌, lit. wealth clan in Korean), thus were capped by tycoon or business family-controlled apex firms with multiple listed subsidiaries, each with listed subsidiaries of their own, and so on. However, the families, fearing loss of control, were reticent about too much dilution of their inter-corporate control stakes. To push them along on his $\mathrm{HCl}$ 
drive, Park had to continue the flow of subsidies.

As in Japan, government bureaucrats were credited with planning the development of these key industries. At first, the state was quite likely directing the chaebol (Amsden 1992; Woo 1991), rather than the converse. Woo-Cumings' (1999) sees a genuine "state-capital partnership" of equals. Lim (2000) and Hundt (2009) see an alliance. But, by the end of the 1970s, the balance had shifted and the chaebol were widely perceived as having captured the state (Luedde-Nerath 1986; Chibbers 1999, 2005). Also as in Japan, the prescience of the government planners may well be exaggerated. Park's $\mathrm{HCl}$ Drive was restricted to a narrow set of firms, and his drive to generate foreign exchange had a narrowly focused goal. Both were clearly important interventions, but no broader state direction of the economy appears consequential during the Park years.

When asked why Lucky Goldstar (LG), one of Korea's largest chaebol, established new firm after new firm, the patriarch of its controlling family, Koo Cha-Kyung, made no mention of guidance from government technocrats. Rather, Koo explains (Kim and Lee 2010) how

"My father and I started a cosmetic cream factory in the late 1940s. At the time, no company could supply us with plastic caps of adequate quality for cream jars, so we had to start a plastics business. Plastic caps alone were not sufficient to run the plastic molding plant, so we added combs, toothbrushes, and soap boxes. This plastic business also led us to manufacture electric fan blades and telephone cases, which in turn led us to manufacture electrical and electronic products and telecommunications equipment. The plastics business also took us into oil refining, which needed a tanker shipping company. The oil refining company alone was paying an insurance premium amounting to more than half the total revenue of the largest insurance company in Korea. Thus, an insurance company was started. This natural step-by-step evolution through related businesses resulted in the Lucky-Goldstar (LG) group as we see it today."

Conceivably, Koo was reticent about crediting government planners. However, accounts of Park's thoughts at the time support Koo's version of events. The general was dismayed about the chaebol families' unpatriotic dereliction of duty in diverting $\mathrm{HCl}$ subsidies into other sectors, such as consumer electronics and automobiles (Hundt 2009, p. 68).

The member firms in these pyramidal groups clearly engaged in complicated inter-corporate crosssubsidies or "tunneling" (Lim 2012). This may have been, as Koo explains, to set up new firms to fill in 
missing links in production chains or to expand existing firms to accommodate the needs of other group firms. This sort of tunneling is growth enhancing if consistent with the chaebol coordinating a privatesector "scheme of planned industrialisation comprising a simultaneous planning of several complementary industries" that Rosenstein-Rodan (1943) thought impossible. Morck and Nakamura (2007) argue that such a scheme was accomplished by Japan's late $19^{\text {th }}$ and early $20^{\text {th }}$-century zaibatsu pyramidal groups, and South Korea's chaebol may well have followed suit.

Like Japan's great zaibatsu, Korea's largest chaebol groups attained "full set" diversification: each had at least one member firm in every significant sector. Also like the zaibatsu member firms, a chaebol's member firms preferred doing business with each other and avoided dealing with member firms of another chaebol, as might be expected if avoiding hold up problems were paramount. Again like the zaibatsu, the largest chaebol competed with each other, at least in export markets.

The chaebol may also have competed with each other domestically, but the largest among them were now so huge that cartelization became a concern. Perhaps more important, the tycoons and heirs controlling the major chaebol wielded vast economic power, which begat vast political influence. In the 1960s, the government could credibly claim to be directing the chaebol. By the late 1970s, their positions were widely thought reversed.

When Park seized power in 1961, South Korea's per capita income was barely half that of North Korea. Despite recurring financial crises, South Korea had pulled far ahead and well into the ranks of middleincome economies by the late 1970s. Many South Koreans remained poor and inequality was stark, but a middle class was forming. Modern buildings were rising, and parts of Korean cities looked decidedly prosperous. North Korea was clearly trailing ever further behind.

\section{Chun Doo-hwan and the Transition to Democracy}

By the late 1970s, Park's HCL subsidies were out of control: inflation was soaring and foreign debt was $50 \%$ of GDP and another financial crisis loomed. In 1979, Park decided to end subsidies to businesses. But before his decision could be announced, he was assassinated by the head of the secret service. The military turned to General Chun Doo-hwan, who ruled from 1980 to 1987 . Chun took over a bankrupt government with no prospects for borrowing more money and, to gain international aid, reluctantly acquiesced to liberalizing the economy. Subsidies ended, save for limited research and development 
support. Like Japan a century earlier, in 1980 South Korea turned to laissez-faire economics as a desperate last resort when all other options were closed off.

South Korea's acquiescence to free market economics was less complete than Meiji Japan's. While productivity-levels in South Korea were rising towards those of high-income countries, South Korean wages were kept comparatively very low. A rising labor movement sought pay increases commensurate with Korean workers' rising productivity. To preserve Korean firms' global labor cost advantage, Chun's government ruthlessly suppressed labor unionization.

Unlike Meiji Japan at this stage, South Korea had yet to establish a functioning democracy. To suppress criticism of his use of police power against labor, Chun imposed state security measures that, to many, seemed more brutal and intrusive than those of the Park era.

Widespread labor actions and student protests brought down the military dictatorship in 1987. South Korea established a multiparty democratic government, and became a stable democracy. Under democracy, wages rose rapidly, approaching those of other high-income countries by the mid-1990s.

The established banks, kept independent of the chaebol, were reluctant to grant industrial development loans. The chaebol consequently relied mainly on equity issues to expand existing firms and capitalize new pyramid member firms. However, this risked unacceptably diluting the inter-corporate equity stakes that held the chaebol together. To obtain debt financing, the chaebol established non-bank financial institution member firms which then lent to other chaebol member firms of the chaebol at lower rates than banks offered to independent firms. This appears to have reflected some mixture of financial self-dealing within the group, chaebol member firms propping each other up to reduce their bankruptcy risk (Yafeh and Khanna 2007; Bae et al. 2008) and lenders' believing the chaebols to be too big (or too politically connected) to fail (Gormley et al. 2015). ${ }^{15}$

The chaebol continued to expand, largely through share issues. Sprouting new listed subsidiaries, the chaebol diversified further away from their heavy and chemicals industries focus. The transition to democracy appears to have forced a change in the chaebol's strategy (Mo et al. 2013). Henceforth, rapidly rising wages diminished Korea's labor cost advantage, but increasingly well-paid paid Koreans became an increasingly lucrative domestic market.

\footnotetext{
${ }^{15}$ The chaebol were reliably bailed out except during in a brief period in the 1990s (Minnett and Yun 2015)
} 
Investment, barely ten percent of GDP under Rhee, and around twenty-five percent of GDP under Park, rose to nearly forty percent of GDP under democracy. South Korean per capita GDP rose rapidly, as productivity rose rapidly (Young 1995). ${ }^{16}$ Foreign and domestic investors, seeing the huge returns generated as this newly high-income economy formed, poured still more capital into South Korea; and into other East Asian economies that seemed good bets to become high-income economies as well. Kwon and Hwon (1995) find evidence of capital misallocation as this excess supply of capital became a stock market bubble that expanded and then burst in the 1997 Asian financial crisis. ${ }^{17}$ After a brief recession, productivity growth resumed, albeit at a slower pace consistent with a maturing economy and amid concern about the suitability of the chaebol corporate governance model going forward (Lim and Hahm 2006).

Throughout all of this, the chaebol dominated the South Korean economy. Baek et al. (2004) report that chaebol firms took longer to recover, especially if they were more leveraged and their controlling shareholders actual ownership (cash flow rights) were smaller. The chaebols' eventual recovery may have been aided by their substantial ongoing domestic market power (Jeong and Mason 1990; Yang and Huang 1994; Aw et al. 2003).

Johnson et al. (2000) define as income transfers between member firms of a business group designed to augment the wealth of the controlling shareholder at the expense of the income donor firms' public shareholders. Bae et al. (2002), Joh (2003), and Baek et al. (2006) report credible evidence of extensive tunneling between member firms of chaebol before and during the 1997 crisis.

While potentially harmful to the share valuations of the income donor firms, tunneling between member firms of economy-spanning business groups can facilitate the coordinated development of firms in multiple interdependent sectors that Rosenstein-Rodan (1943) identifies as key to rapid development. Almeida et al. (2011) report that the chaebol grew in two ways: (1) their controlling families acquired and held direct equity ownership of high-earnings firms and (2) listed chaebol member firms acquired and held control blocks in low-earnings firms. The second of these tended to decrease the acquirer firms' share prices. However, new chaebol member firms appear to have been critical to

\footnotetext{
${ }^{16}$ Young (1995) argues that other studies linking most of South Korea's growth to factor accumulation mismeasure its productivity growth. See Ramazani and Markus (1993), Park and Kwom (1995), and others.

${ }^{17}$ Foreign capital inflow prior to the crisis suggests herding, but foreign investors appear to have played a stabilizing role during the stock market collapse by buying securities domestic investors were selling (Choe et al. 2005).
} 
the economy's productivity growth (Feenstra et al. 1992). Also, Almeida et al. (2015) present evidence that inter-corporate wealth transfers between each chaebol's member firms were efficiency-improving in the sense that capital flowed towards firms with more valuable growth opportunities.

The political influence of the chaebol remained, and successive democratic governments did little to curtail it. Measures to regulate their inter-corporate equity control block structures merely altered those structures without compromising the power of the controlling families. By the early $21^{\text {st }}$ century, the tycoons who had founded the great chaebol business groups were largely gone and control had passed to heirs and to heirs' heirs. Concerns about the competence of the new generations of controlling shareholders grew as scandals grew more brazen.

Japan's zaibatsu never got to this stage. Japan's wartime military dictatorship imposed central planning on the zaibatsu, effectively sidelining their controlling families. After the war, the American occupation government seized the control blocks in zaibatsu member firms and relaunched them as freestanding widely-held listed corporations. Such high-handed tactics were impossible in democratic South Korea.

The incongruity of what many Koreans deem a feudal corporate governance system in an otherwise egalitarian democracy invites corporate governance reform. However, the chaebol families economic, and hence political, influence make this a vexing political economy challenge (Haggard et al. 2003). Defenders of the status quo point to the survival of pyramidal business groups in other high-income countries. Canada was dominated by highly leveraged pyramidal groups in the 1990s, but these broke up when interest rates spiked in the 1990s (Morck and Tian 2017). Kim (2016) suggests similar vulnerabilities may be developing in Korean chaebol. Sweden's economy remains dominated by large pyramidal business groups, but their longevity appears due largely to political connections, rather than high productivity (Hogfeldt 2005). Moreover, Swedish firms exhibit valuation patterns consistent with tunneling (Bjuggren \& Palmberg 2010) and debate about the future of Swedish business groups continues (Henrekson \& Jakobsson 2003; Larsson and Petersson 2017).

Chaebol reform returned to Korean headlines in 2017 when a corruption scandal involving Samsung heir Lee Jae Yong led to his arrest and the impeachment and imprisonment for corruption of President Park Geun-hye, the daughter of General Park Chung-hee. Calls for the democratization of South Korean corporate governance resumed. The most prominent model for dismantling Korea's chaebol is the United States, where a series of New Deal corporate governance reforms in the 1930s legislated that 
country's pyramidal business groups out of existence (Morck 2005; Kandel et al. 2017) by taxing intercorporate dividends and estates, subjecting firms whose major assets are shares in other firms to regulation as mutual funds, and limiting the number of tiers in pyramids in regulated public utilities. None of these reforms was sufficient alone, but together they left the United States almost without major pyramidal business groups by 1950 . The most recent example of a country forcing the dismantling of its pyramidal business groups is Israel. There, a campaign led by the pro-market Israeli business newspaper The Marker culminated in the 2013 Law for Promotion of Competition and Reduction of Concentration, which limits pyramids to two tiers of listed firms controlling listed firms. Given prior reforms precluding the issuance of dual class shares (Hauser and Lauterbach 2004), this effectively limits the scope for separating ownership from control via pyramiding.

\section{How China is Growing Rich}

\section{China's Great Reversal}

For centuries, China's economy was large and comparatively advanced (Brandt, Ma and Rawski 2014). ${ }^{18}$ Even in the mid- $19^{\text {th }}$ century, China was still the largest economy in Asia and larger than the US economy Bolt and Zanden 2014). In the late $18^{\text {th }}$ and $19^{\text {th }}$ centuries, China had sophisticated private-sector banks with nationwide branch networks based in Shanxi, the inland terminus of the "tea road" caravan route to Russia (Morck and Yang 2011; Huang 1992). The Rishengchang Bank, the first of the Shanxi banks, was perhaps also China's first joint stock company (Morck and Yang 2011).

China's final imperial dynasty, the Qing (1644-1912), oversaw the massive economic reversal that all but ruined the economy. The dynasty entrenched an interlocked patronage-dependent Manchu elite (Brandt, Ma, Rawski, 2013) accustomed to an "iron rice bowl privilege" (Elliott, 2001) and increasingly wary of potentially disruptive Western influence. The dynasty isolated Western trade to the Portuguese enclave at Macau and a small sealed-off section of the riverbank in Guangzhou, which Western merchants could visit briefly, under close supervision, and subject to the sometimes arbitrary caprices of local bureaucrats, to trade with a small number of approved Chinese merchants. These state-sanctioned

\footnotetext{
${ }^{18}$ Brandt, Ma, and Rawski, 2014 present a comprehensive and excellent review of China's economic history from the Song Dynasty (960) to the reforms of the 1990s.
} 
monopolists sold Western merchants tea, silk and other Chinese products for silver. British merchants, seeking a more advantageous medium of payment, turned to selling Indian opium to Chinese merchants. This soon reversed the flow of silver (Brandt, Ma, and Rawski 2014).

To combat the rapidly growing opium addiction problem, the dynasty forbade the opium trade and seized and destroyed all opium inventories in 1839. The British government, objecting to the seizure, sent in gunboats that quickly routed Chinese defenses in the First Opium War. The 1842 Treaty of Nanking, China's first "unequal treaty", opened five ports to British merchants, granted them extraterritorial legal rights, and ceded Hong Kong to Britain.

Civil wars worsened China's situation. Hong Xiuquan (1814-64), an unsuccessful civil service examination candidate and the self-proclaimed little brother of Jesus, led the worst of these, the Taiping Heavenly Kingdom Rebellion (1850 - 1864). At its acme, the rebellion severed southern China from Beijing, cutting off internal trade and communications. The rebellion's strength reflected "increasing poverty, natural disasters, and incompetent government" (Schrecker 2004). Regional officials ultimately suppressed the rebellion and restored Qing rule across China. The ensuing Tongzhi Restoration (1861-75) saw an "effort to restore stability and prosperity by revitalizing orthodox Confucian ideology ... and restoring regular civil service examinations" (Brandt, Ma, and Rawski 2014).

Ongoing attacks on British subjects and continued resentment over opium sparked the Second Opium War (1856 - 1860). Defeated again, China acceded to open more ports, create more extraterritorial legal enclaves, and legalize opium and Christianity. China continued losing conflicts with Western powers and later Japan, opening more treaty ports protected by extraterritoriality with each defeat (Brandt, Ma, Rawski, 2014, p. 81). Japan gained suzerainty over Korea and colonized Taiwan in 1895. Russia seized Manchuria the same year. Germany took Qingdao in 1898. Anti-foreign, anti-colonial and anti-Christian sentiment intensified.

As in Japan, views divided about responding to the outside world. Hostility towards foreigners, viewing them as a contamination to be eradicated, vied with arguments that China could only be saved by adopting and adapting foreign ideas. However, unlike in mid- $19^{\text {th }}$ century Japan, where the latter view won overwhelmingly, the debate continued at all levels in late $19^{\text {th }}$ century China. The pro-reform "selfstrengthening" movement succeeded in reforming customs, initiating modernization of the military, and establishing the Imperial Bank of China in 1897. High-level Qing mandarins led efforts in modernizing 
China's navy and tried to establish heavy industries such as steel mills. In 1898, the Emperor Guangxu launched the Hundred Days' Reform to curtail corruption, reform the military, and modernize education by introducing medicine, science, and commerce and abolishing the Confucian-literature-based civil service exam. The measures threatened entrenched elites, who rallied behind the Dowager Empress Cixi to overthrow Guangxu and end the reforms. Furious about foreign influence challenging her monopoly on power, Cixi endorsed the Boxer (Yihutuan, lit. Righteous Fists) Rebellion in 1900. Initially an antiforeigner militia, the Boxers killed foreign civilians, diplomats, missionaries and Chinese Christians. This brought Western and Japanese troops into Beijing in 1901. Each successive conflict and loss to foreigners accentuated China's backwardness, drained its finances with new rounds of reparations payments, deepened the entrenched elite's opposition to the modernization that might have led to economic recovery, and dimmed reformers' hopes for a policy reversal.

The Shanxi banks faded away amid this chaos, and economic activity found refuge in the enclaves of foreign extraterritorial jurisdiction created by the "unequal treaties." Shanghai, a major port for maritime trade from the latter $19^{\text {th }}$ century on, hosted a new generation of Chinese banks (Ji 2003). Foreign banks arose to finance trade with the West - notably the Hong Kong and Shanghai Banking Corp (HSBC). The Bank of Communication, established in 1908, still exists. A foreign-stock trading house (shanghao) facilitated the trading of foreign shares in the foreign concessions of Shanghai from the 1860s on, and a Hong Kong analog (Xiang-gang gupiao jingji xiehui) was formed in 1891. Markets for Chinese shares only developed as the Qing dynasty fell. The first, active in 1911, was the Beneficent Fragrance Tea House in Shanghai.

The Dowager Empress Cixi died in 1908, a day after the death of the Emperor Guangxu and enthronement of the three-year-old "last emperor," Puyi. In 1911, the Qing Dynasty collapsed, and history records the establishment of the Republic of China in Nanjing by Dr. Sun Yat Sen. In reality, China became a mere geographical expression, with sovereign warlords ruling former imperial provinces. The Republic of China army, subsequently led by General Chiang Kai-chek, vied with Mao Zedong's communist guerrillas to gain control, often by co-opting regional warlords. Japanese invasions from 1931 on seized the Manchurian provinces and then penetrated deep into China. The civil war facilitated Japan's advances until 1937, when the Chang reluctantly agreed to combine forces with Mao's guerrillas. After Japan surrendered to the United States in 1945, full-scale civil war resumed in 1947.

The period from 1850 to 1949 has been called China's century of humiliation. Its political system and 
economy both collapsed. Bolt, Timmer, and van Zanden (2014) reports China's 1850 per capita GDP at $\$ 600$ (1990 US dollars) and Japan's at \$681. By 1950 China's per capita GDP was down $25.3 \%$ to US\$448, while Japan's had risen $182 \%$ to $\$ 1,921$.

\section{Mao Blanks the Slate}

Mao's Communist Party of China drove Chiang's Republic of China onto the island of Taiwan in 1949. The Communist victory was widely attributed to endemic corruption on Chang's side of the civil war. The People's Republic of China nationalized all businesses in the early 1950s and imposed Soviet-style central planning, which effectively eradicated private markets. Owning a private business employing more than a handful of people was made a crime. Land reforms in 1952 expropriated all farmlands to establish collective farms. SOEs and communes took charge of all manufacturing, with central planners decreeing prices, production quotas, investment allocations, and employment assignments. The state assigned university graduates to jobs and controlled their lifelong careers. Consumer goods were allocated via ration coupons.

Once firmly in power, the Communist regime set about deepening China's economic collapse. The Korean War (1950 - 1953) and Sino-India War (1962) renewed China's isolation from the emerging postwar world order. Mao launched a rapid succession of political campaigns aimed at solidifying control, settling internal power struggles, and promulgating ideological purity - the CounterRevolutionary Campaign (1951-52), Hundred Flowers Campaign (1956), and Anti-Rightist Movements (1957-59) - that left Party cadres and the population at large cowed and submissive. This let Mao launch the hugely destructive Great Leap Forward (1958 - 1962), which moved peasants off the land to run village iron smelters. Starvation soon set in, even as desperate villagers deforested the countryside to fuel their smelters, melted cooking pots to make their quota, and left their collective farms' fields to erosion. Ultimately, the sheer scale of the unfolding disaster marginalized Mao. To renew his political power, Mao launched another political campaign, the Cultural Revolution (1966 - 76), which dealt the economy a final blow by purging educated people from factories, government offices, schools and universities to make way for ideologically pure Maoists.

After its century of humiliation, China underwent twenty-seven more years of political turmoil and economic reversal. Bolt, Timmer and van Zanden (2014) record China's per capita GDP (in 1990 US dollars) rising a mere US\$14 (2.1\%) from 1950 to 1960, while Japan's rose US\$2,095 (107.2\%). China's 
per capita GDP in the 1970s was among the lowest in the world. The sole silver lining in Mao's legacy is that he left China a blank slate. China, its extractive elite thoroughly devastated, was, like South Korea, ready for institutional reforms (Acemoglu et al. 2002).

\section{China's Economic Reforms Begin in 1978}

Before dying in 1976, Mao designated Hua Guofeng his successor, who soon ended the Cultural Revolution. Deng Xiaoping, a pragmatic reformer, exiled by Mao, regained political influence and pressed for economic reforms. The $3^{\text {rd }}$ Plenary Session of the $11^{\text {th }}$ Central Committee of the Communist Party of China (Dec 18 -22 1978) officially adopted Deng Xiaoping's reforms, which put economic pragmatism before political ideology.

By any standards, Deng's reforms, and the further reforms that followed, were blazingly successful. China's real per capita GDP rose from levels comparable with the poorest countries in sub-Saharan Africa in 1977 to levels comparable with better performing economies in Latin America in 2015 (about US\$6500 in 2010 constant dollar), its real growth rate averaging some 10\% per year. The reforms made China a rising middle-income economy: its 2015 per capita GDP roughly matching South Korea's in 1986 (Morck and Yeung 2016), and China shares many of the problems typical of middle-income economies. Development is decidedly varied across provinces and between urban versus rural areas, environmental degradation is reaching dangerous proportions (Ebernstein, 2012; Zheng and Kahn 2013, 2017; Ebenstein et al. 2015), debt is burgeoning (Zhu 2016), and inefficient resource allocation is depressing productivity (Hsieh and Klenow 2009). China's development is very much a work in progress.

\section{China's Financial Reforms Paradox}

Persuasive work in financial economics argues that financial development is intimately related to economic development (King and Levine 1993), and the rapid development of Japan and Korea described in the previous sections support this view. China's financial development has been much more constrained. Before the reforms, China had only one bank, the People's Bank of China, which implemented the Central Plan by collecting and reallocating the revenues of all communes, factories and other organizations. The reforms made the People's Bank of China the central bank, divesting it of operations that became four huge state-owned banks: the Bank of China, China Construction Bank, Agriculture Bank of China, and Industrial and Commercial Bank of China. All four now rank among the 
largest banks in the world. The Bank of Communications, founded in 1908, was recreated in 1987. Still, although a few foreign banks have limited operations in China, all Chinese banks remain state-owned. China's stock markets, the Shanghai and the Shenzhen stock exchanges, founded in 1990, also rank among the largest stock markets in the world by total market capitalization. But most firms listed on both, especially the largest among them, are controlled, directly or indirectly, by the state. Many also have comparatively small public floats.

On the surface, China's financial development looks impressive; but the state retains control of the economy's financial commanding heights to an extent that neither Japan nor South Korea ever sought. Various studies present evidence suggesting that China's finance sector plays little role in promoting efficient capital allocation (Deng et al. 2015; Fan, Morck, and Yeung 2012; Allen, Qian, Shan, Zhu 2015) and still gives SOEs privileged access to capital (Allen et al. 2012). Others express concern that China's seemingly global best practice banking and financial regulations are window dressing, enforced optionally at the discretion of Party officials (Allen and Shen 2012). The Constitution of the People's Republic of China enshrines Party leadership, making proscriptions of Party influence over regulatory and legal decisions effectively non-binding. Fan, Morck, and Yeung (2012) argue that "reforms that would let capital market forces allocate savings impartially to their highest value uses ... [would] make high growth sustainable", but the credibly of any such reforms would remain unclear.

\section{Disaster Reversed}

China's rapid economic success from 1978 to 2015 might suggest that further reforms are not necessary. The argument that China is doing fine with the system it has runs up against the stylized fact that a country's growth rate can be higher if it starts out very low (Barro and Sala Sala-i-Martin (1976). China in 1978 was a profoundly broken economy, devastated by a century of Qing collapse, civil war, invasion, more civil war, and then by decades of ideologically-driven Maoist economic failure. China had done so much wrong that merely reversing the most egregious economic mistakes with virtually any economically sensible reforms permitted growth.

China's course reversal was gradual. It retained the old order alongside experimental market reforms with a Dual Track System (Wu and Zhao 1987). The first reforms, launched in 1978, granted a degree of autonomy to a few villages via the Household Responsibility System. Local managers were made responsible for the profits and losses of an enterprise. Bolstered by positive results from this 
experiment, the State Council (cabinet) introduced in 1984 the Contract Responsibility System. Communes were decollectivized and divided into plots assigned to individual farmers, though without ownership rights. Farmers could grow whatever they chose if they also met (greatly reduced) state production quotas.

Another parallel experiment began in factories in 1978. Six selected enterprises were allowed, after making their production quotas, to keep a proportion of their profits for re-investing, employee bonuses and other benefits. Previously, production targeted quotas and all revenues reverted to the state for reallocation under the Central Plan, the enterprise retaining no profits. By the end of 1979 , over 4,200 enterprises had joined the program. In 1980, 6,600 large and medium-sized state-owned production units, accounting for $70 \%$ of industry output, were participating (China Labour Bulletin, 2007).

From 1984 to 1992, the Dual Track system was formalized. State owned factories, then the only meaningful production unit, could sell their products at state-set prices in exchange for centrallycontrolled supplies to fulfill their obligations to the Central Plan, and could then sell any excess output at unregulated prices, typically far higher. Initially, output sold outside the Plan could not exceed $20 \%$ of the total, but the ceiling was gradually raised and then eliminated. State-owned factories met state quotas, paid taxes, retained profits, made decisions, including hiring, firing and bonuses, and could even borrow from the state-controlled People's Bank of China. Yet many struggled with bureaucracy and interfering Party cadres. Production and productivity nonetheless rose, and market transactions expanded rapidly, eventually rendering state quotas all but irrelevant. The state still controlled "strategic industries," but Central Plan prices and quotas faded away over the subsequent decade (Lawrence and Qian, 2000, Qian 2003).

The partial liberalizations of the 1980s also allowed the formation of Township and Village Enterprises (TVEs) in rural areas. These filled market gaps, particularly in light industries (Naughton 2000). Many TVEs, though collectively owned and sponsored by local governments, were effectively controlled and run by individuals. Many were also financed with loans from state banks. Huang (2012) argues that, "township and village enterprises from the inception have been private and that China undertook significant and meaningful financial liberalization at the very start of reforms ... [they] contribute to China's poverty reduction, GDP growth driven by personal consumption ....and an initial decline of income inequality." However, most TVEs fell apart amid ill-defined property rights (Kuyng and Lin 2007). 
Thus, from 1978 through to the late 1980s, China transitioned out of Soviet-style central planning with the emergence of enterprises exercising decentralized decision-making and financed by the state bank. This Dual System was popular for making goods and services more available. However, it also invited abuse: some people grew wealthy obtaining goods at state prices and reselling them in free markets. Some state-owned factories in the "planned" sector hid their true capacities and production, letting factory managers pocket proceeds from selling the surpluses into the free market.

\section{Rejoining the World}

Before the 1978 reforms, the economy was tightly closed. Only a trickle of foreign trade by state-owned factories existed, mainly flowing through Hong Kong. Keller, Li and Shiue (2011) link about 2\% of global trade to China before World War II, but find China's share "fallen by the 1950 s to around $1.7 \%$ and by the 1970s to around 0.7\%." Data are sparse given China's anti-economic and inward-looking political atmosphere under Mao. Such trade as occurred was of agricultural products and raw materials such as oil.

After 1978, foreign trade was gradually liberalized and increasingly market-driven. Reforms and openness became a signature slogan of 1980s economic policies. Lardy (2003) writes "China undertook (unilateral trade liberalization measures) during the reform period, even before its accession to the World Trade Organization. By a number of measures China transformed its economy from one of the most protected to perhaps the most open among emerging market economies."

Special economic zones to facilitate trade were established in Guangdong (Shenzhen, Zhuhai, and Shantou) and Fujian (Xiamen) after 1980. By 1984, 14 coastal cities featured such zones. ${ }^{19}$ By 1992, China had 15 free-trade zones and 32 economic and technology development zones. All these zones administered preferential policies promoting foreign trade, foreign technology, and foreign direct investment, generally through joint ventures with Chinese partners. Until the mid-1980s, international trade required government permits. Thereafter, tariffs and non-tariff barriers replaced permits to trade; but the state retained control over trade by requiring permits to buy or hold foreign currencies and by imposing artificially disadvantageous foreign exchange rates, with all sales of foreign currencies

\footnotetext{
${ }^{19}$ Dalian, Qinghuangdao, Tianjin, Yantai, Qingdao, Lianyungang, Nantong, Shanghai, Ningbo, Wenzhou, Fuzhou, Guangzhou, Zhanjiang and Beihai.
} 
permitted only through the Bank of China. ${ }^{20}$ Still, if a factory earned foreign currencies from exporting, these could be used to buy foreign machines. These measures encouraged market-driven exports while regulating imports. Trade (exports plus imports) rose from 15\% of GDP in 1980 to $21 \%$ in 1984 and 35\% in 1986.

China permitted inward foreign direct investment via joint ventures mainly to encourage the importing of foreign technology and management practices. Although China entered into many bilateral investment treaties in the 1990s, managed inward foreign investment for the advancement of China's growth remains the overriding policy. China's 2001 accession to the World Trade Organization (WTO) led to considerable liberalization of service sector and further loosened restrictions on foreign investment. Banking, financial services, insurance and telecommunications were opened to foreign investment, albeit still subject to substantial restrictions. (Lee 2008). By 2013, additional reforms had greatly raised the de minimus threshold for provincial government approval of foreign investment projects and replaced merger notification discrimination against foreign investors with a national security review process for cross-border M\&As (Davies 2013).

Abandoning the Qing and Communist era aversion to foreign trade was arguably instrumental to China's economic recovery. A World Bank report states: "According to the Ministry of Commerce (MOFCOM), foreign invested enterprises account for over half of China's exports and imports; they provide for $30 \%$ of Chinese industrial output, and generate $22 \%$ of industrial profits while employing only $10 \%$ of labour - because of their high productivity. ${ }^{21}$ Evidence on technology spillovers is more limited, but industries with higher FDI seem to have higher productivity increases than other industries, suggesting a positive effect. Importantly, foreign investment has catalyzed China's economic reform. Together, these contributions have supported China in maintaining a record-high 10 percent growth rate during most of the 1980-2010 period."

\section{Re-investment in Human Capital}

Meiji Japan was an unusually literate society, and Syngman Rhee's sole unambiguously positive legacy to

\footnotetext{
${ }^{20}$ The dual exchange rate was eliminated in 1995, but the officially pegged Yuan was substantially devalued: from 6 yuan per dollar to 8 yuan per dollar, where it remained until almost 2004. China still tightly restricts individuals' purchases of foreign currency.

${ }^{21}$ Foreign Direct Investment - the China Story, July $16^{\text {th }} 2010$.
} 
South Korea was universal public education. In both countries, education made foreign technology and ideas look more like opportunities than threats. China's formal higher education has a relatively short history. The Qing only established Peking University in 1898, under pressure from the Self-Improvement Movement; though a quasi-university, the School of Combined Learning (Tongwen Guan) dated back to 1862. University education survived the civil wars and Japanese invasion, but ceased totally during the Cultural Revolution from 1967 to 1976 (Chang 1974, Chandra 1987), Indeed, in 1976 even high schools closed: China had over 930 million people but only about 48,000 high school students. China had long neglected general education, and the Cultural Revolution only made things worse. China's literacy rate in 1981 is estimated at only $65.5 \% .^{22}$

Deng Xiaoping reversed these policies, reopening universities and resuming the National Higher Education Entrance Examination (Gao Kao), in 1977. People responded enthusiastically, many resuming studies interrupted years ago. In 1978, Deng made a strategic decision to send 3,000 students and scholars abroad every year for further education, famously asserting "When our thousands of Chinese students abroad return home, you will see how China will transform itself." Pursuing higher education overseas became the enthusiastic pursuit of many bright students. Although China's universities were also bolstered by foreign professors sent under the auspices of many countries' foreign aid agencies, studying overseas was soon seen as a golden ticket to prosperity. China's living standards remained far below those in the developed world, and many who studied abroad opted to stay. Confronting complaints about a "brain drain", General Secretary Zhao Ziyang responded that China was "storing brain power overseas." As China's prospects improved in the early $21^{\text {st }}$ century, many returned. By 2001, returnees ran over 1,700 private firms in Shanghai alone (Zweig and Rosen 2003). Firm performance also rises significantly upon hiring a returnee as a director (Giannetti, Liao and Yu 2015). These findings are consistent with returnees bringing foreign technologies and entrepreneurship to China, and with Zhao's contention that their pursuit of self-interest would ultimately benefit the overall economy.

\section{Financial Development Resumed}

Chinese were now seeing life in the outside world, and foreign ideas and goods were flowing into China. The Dual Track System had raised expectations, but created huge distortions, high inflation, and widespread resentment about corruption. These grievances culminated in the 1989 Tiananmen Square

\footnotetext{
${ }^{22}$ World Bank, World Development Indicators.
} 
incident. The "event" stalled reforms, which resumed only after Deng Xiaoping visited Shenzhen in Dec 1992 to reaffirm China's need for further economic liberalization. Several major reforms ensued.

A key reform was the 1994 Company Law, under which state-owned factories were corporatized into state-owned enterprises: limited liability companies with well-defined assets and liabilities. This was designed to overcome the problem of ill-defined property rights that undermined TVEs a decade before. In 1997, Premier Zhu Rongji announced a "grasp the big, let go the small" (zhua da fang xiao) reform: letting small and medium-sized state-owned enterprises be restructured into private-sector firms through employee buyouts, open sales, joint ventures, mergers, or bankruptcies; the state retaining ownership of large state-owned enterprises. The reformers' objectives were multifold: to divest small and inefficient state-owned enterprises, to limit job losses by retaining control of state-owned enterprises with large workforces; to retain control over the earnings of profitable SOEs such as those in the resources sector, and to control SOEs with strategic implications for the scope of the Party's ongoing social and economic control, such as those in finance, infrastructure, energy, transportation, and heavy industries (Qian 2000; Chiu and Lewis 2006; Brandt et al. 2008; Fan and Hope 2013; Li and Yamada 2015). The Shanghai and Shenzhen stock markets, established in 1990 and 1991, now permitted corporatized SOEs and even some privatized firms to raise funds by issuing shares (Allen, Qian, Shen and Zhu 2015).

Another key 1994 reform created three state-owned Policy Banks: the Agricultural Development Bank of China, China Developed Bank and Export-Import Bank of China. As mentioned above, a 1995 reform also carved four new state-owned banks - the Bank of China, China Construction Bank, Agricultural Bank of China and Industrial and Commercial Bank of China - out of the People's Bank of China, which became the central bank. City-level commercial banks were permitted in 1996 (Elliott and Yan 2013). Although a few foreign bank established limited operations in China, the state's direct control of the banking sector remains overwhelming, easily exceeding 96\% in 2009 (Deng et al. 2015, Table 3) Allen et al. (2005) report China's banks' primary function to be the channelling of national savings into loans to SOEs.

State owned enterprises still commanded the heights of the economy. From 1998 to 2002 SOEs accounted for over half of total assets and employment in industry enterprises (Gang and Hope, 2013, Figure 1, p. 7). SOE inefficiency was a growing concern, as China's GDP growth rate slowed from $14.3 \%$ in 1992 to $7.6 \%$ in 1999. Some SOEs also had difficulties paying back loans to state-owned banks, whose nonperforming loans rose to $20 \%$ and $22.5 \%$ of GDP in 2000 and 2001, respectively, levels far higher 
than in the US, Japan, Korea, India, Indonesia or Taiwan (Allen et al. 2012).

A new round of reforms followed the $200216^{\text {th }}$ National Party Congress, under Zhu Rongji. The State Council formed the State-owned Assets Supervision and Administration Commissions (SASACs) in 2003 to act as a single holding company owning all shares in all SOEs, except state-owned banks and to guide and supervise further SOE reforms. (Deng et al. 2015). All non-performing SOE loans were moved at book value into four asset management companies. Also in 2003, shares in state-owned banks were purchased by the Central Huijin Investment Ltd, a branch of the State Association for Foreign Exchange (SAFE), an administrative agency subordinate to the People's Bank of China (PBOC). This was organized as a share purchase so the state could inject capital into the banks while offloading their nonperforming loans. Huijin now serves as the state holding company for state-owned banks. In 2007, Central Huijin Investment Ltd was corporatized as a subsidiary of $\mathrm{CIC}$, China's newly formed sovereign wealth fund (Pistor, 2010). Central Huijin's corporate charter specifies that its management and supervisory boards be appointed directly by the State Council (Pistor, 2010). Bank regulation was assigned to the China Bank Regulatory Commission (CBRC), founded in 2003.

\section{An Investment Boom Begins}

This new institutional framework gave the Party tight control over all large state-owned enterprises and banks. The State Council directly oversees the SASAC, which in turn controls the SOEs. The party reinforces this control via its Organization Department, which determines the salaries, appointments, reappointments and promotion of all top executives at the SASAC and all SOEs (Deng e.t al 2015; Wu et al. 2014). The People's Bank of China, CBRC and the Ministry of Finance regulate and supervise the state-owned banks, which are formally controlled by the CIC through Central Huijin Investments. Here too, the Party, through the Organization Department, determines the compensation, appointment, reappointment, and promotion of every top level executives of all of the above. Top executives at both state-owned enterprises and banks, their Chief Executive Officers and Party Secretaries, therefore have a strong incentive to put loyalty to the Party before corporate financial performance, even though profitability is nevertheless a performance indicator (Deng et al. 2015).

Since the 1978 reforms, the Party has linked its legitimacy to delivering economic growth and social stability. This means top executives at banks and nonfinancial SOEs are effectively enrolled in a country wide promotion tournament for delivering tangible growth subject to a Party loyalty constraint (Li and 
Zhou 2005, Wu et al. 2014). The Party leadership promotes GDP growth by ordering state-owned banks to lend to SOEs to boost investment. Top executives at both, aspiring for promotion, comply. Large scale investment spending has an immediate positive impact on GDP, and China's industry and infrastructure were so antiquated and deteriorated that virtually any investment seemed useful. Skyscrapers, renovated town squares, high-speed trains, new airports, steel mills, auto plants, and all manner of new physical assets sprouted everywhere. Deng et al. (2015) show that all of this provided the government an effective short-term economic engineering mechanism for counteracting the 2008 global financial crisis. Xu (2011) argues that this combination of institutions constitutes a "regionally decentralized authoritarian system: the central Party leadership has control over key personnel, whereas subnational governments make detailed implementation decisions: they "initiate, negotiate, implement, divert, and resist reforms, policies, rules, and laws."

Fiscal reforms starting in the 1980s reinforced the trend. Before 1980, the government financed itself off the revenues and profits of SOEs, communes, and all other organizations, all of which accrued to the various levels of government under central planning. Reforms letting these organizations retain much of their earnings necessitated fiscal reforms. After 1994, the central government has collected all taxes, corporate income taxes from financial institutions, and centrally controlled SOEs. Subnational governments receive from the central government $25 \%$ of VAT revenues and were to collect business, excise, and personal income taxes. However, local tax collection efforts proved ineffective. The changes thus substantially increased the fiscal revenue of the central government while reducing those of subnational governments, which turned to land lease sales to finance their operations (Gordon and Wei, 2012).

Previously, Chinese lived in grim state-owned housing projects administered by their work units. Housing reforms started in 1978 which in essence gradually shifted free housing provided by states or work units to self-owned or private rental arrangements. The government adjusted rents upwards in multiple steps and encouraged people to buy their own houses and banks to offer mortgages. Mortgage lending was regularized in 1997 and termination of work unit housing provision was announced in 1998. These reforms led to a real estate development boom, which saw large numbers moving into modern condominiums.

These reforms substantially elevated the market value of land. While all land remains state-owned, local governments distributed or rented land parcels to developers at bargain prices until 2004. In 2004, the 
central government stipulated that all leases of land parcels for development must be auctioned off and that the proceeds serve as local governments' fiscal income. This created a huge incentive for local governments to invest in infrastructure. Party cadres running local governments could boost their odds of promotions by upping infrastructure investment, which mechanically and immediately elevates GDP. Infrastructure development raises the value of nearby land lots, boosting local governments' revenues from their land lease auctions, which in turn raises a government's ability to make more investment further contribute to GDP growth and further boost the promotion odds for the cadres responsible (Deng et al. 2015). Real estate development also boosts local GDP directly, raises the auction value of other land lots, and thus boosts local government revenues further, letting them finance yet more infrastructure construction.

A real estate construction boom ensued. Like cadres running local governments, cadres running SOEs could also boost their odds of being promoted by increasing their SOEs' contributions to GDP growth. Cadres running centrally-controlled SOEs soon saw real estate as a short cut (as compared to capital spending in their own sectors) to generate earnings that would count towards GDP growth and boost their promotion prospects. The banks, all state-controlled, were primed to lend to SOEs, so a massive flow of borrowed funds passed through SOEs into real estate. SOEs in virtually all sectors plunged into real estate development (Deng et al. 2015). In short, the Communist Party promoted an investment boom by forcing cadres to compete for pay and promotion.

\section{China's State-led Big Push?}

The system of incentives described above rapidly developed into an "investment for growth" frenzy. In 2003 , investment surpassed $41 \%$ of GDP, and remained in this range for the subsequent decade. GDP growth simultaneously surged and remained high. In this period, China became the second-largest economy and the second largest trading nation in the world. However, Chinese per capita GDP is at global middle-income levels and remains far below levels in high-income countries, including South Korea and Japan (Morck and Yeung 2016). China's high-income inequality, though typical of other middle-income economies in Latin America and elsewhere, jars with its communist legacy. China's GINI coefficient rose from 30\% in 1980 to 55\% in 2012, far higher than the US figure of $45 \%$ but not greatly different from Colombia's figure of 53.5\%. Regional income disparity and a growing rural-urban income gap (Xie and Zhou 2014) also risk undermining the Party's legitimacy. Rapid growth can counter these problems by "lifting all boats," but China's investment-fuelled growth must ultimately end as 
diminishing returns to capital set in. Further rapid growth must then depend on productivity growth, and China lags the high-income countries in productivity growth (Hsieh and Klenow 2014).

This tide of state-engineered investment-for-growth coincided with substantial growth in sectors less directly under state control and with further expansion of capital markets. A system of listing quotas for ministries and province-level governments left minority public floats in their state-owned enterprises comprising most of the market capitalizations of China's two stock exchanges, Shanghai and Shenzhen. Most of the shares in these SOEs were retained by the state and declared "non-tradable", locking in state-controlled corporate governance. In 2000, the quota system was removed and in 2005 the State Council issued guidelines and principles (Carpenter et al. 2014) governing SOEs' sales of formerly nontradable shares to public investors. The number of listed firms rose from 1,389 in 2000 to 2,994 in 2013 (Allen, Qian, Shan and Zhu 2015, Table IV).

Many private-sector firms also listed their shares during this period. The term "private-sector" can be problematic because many firms so-classified are actually controlled subsidiaries of state-owned enterprises or otherwise indirectly controlled by governments, government agencies or top Party officials (Allen and Shen 2015; Allen et al. 2015). Still, the fraction of stocks classified as SOEs fell steadily during the 2000s to about half by 2010 (Lardy 2014, p. 113). More recently listed firms are generally smaller, so despite their declining relative numbers, state-owned enterprises remain dominant in valueweighted indexes and account $86 \%$ of the revenue of all listed firms.

Party control of SOEs and firms classified as private-sector is further institutionalized in other ways. Corporate governance in China had a veneer of global best practice regarding independent directors, board committees, and the like. However, the CEO and board of directors of any firm employing four Party members can be complemented by a Communist Party Secretary and Party Committee (McGreggor 2010). These are generally not involved in detailed corporate policy making, and only intervene to prevent the CEO and board from making mistakes. Increasing numbers of listed firms are accepting Party Secretaries and Party Committees, and at least 288 of China's 3,314 listed firms amended their corporate charters to formalize the Leading Role of the Communist Party in their corporate governance. ${ }^{23}$

\footnotetext{
${ }^{23}$ See "Private sector Party committees start to bloom" by Zhang Ye. Global Times July $10^{\text {th }}$ 2016; "Chinese enterprises write Communist Party's role into charters" by Yu Nakamura, Nikkei Asian Review, Aug. $17^{\text {th }} 2017$.
} 
Still, China has two well-functioning stock exchanges and many listed firms with a degree of separation from the state. Chinese equity prices also appear to be more driven by information after the 2000 reforms (Carpenter et al. 2014). However, Chinese listed firms' stock returns are low compared those in developed and large emerging markets, and also to unlisted firms in China, even as China's economic growth outpaced the world (Allen, Qian, Shan and Zhu 2015). Should the government opt to fully privatize more state-owned enterprises, the institutional infrastructure necessary for doing this is ready.

Lending to private-sector enterprises is also developing. Although Allen et al. (2005) show that formal bank credit flowed largely to state-owned enterprises in the 1990s, a finding readily explained by the incentive system described above; they report that informal financing, such as trade credit and other lending by enterprises other than banks may render capital allocation more efficient. ${ }^{24}$ Furthermore, Aayagari et al. (2017) show that, at the beginning of 2002, many private-sector firms were getting loans from state-run banks and that these firms were growing faster and reinvesting more earnings than other private-sector firms, though their productivity growth rates were statistically indistinguishable. ${ }^{25} \mathrm{By}$ 2009, $26 \%$ of bank credit went to private-sector firms; and this rose to $33 \%$ by 2012 (Lardy 2013). Some $9 \%$ of loans also went to collectives both years. This may partly be because private-sector firms outperformed state-owned enterprises (Lardy 2014, fig. 3.8), making the state's credit guarantee for SOEs a less overwhelming factor in state-run banks' lending decisions. But, as with the stock markets, the state has stopped well short of genuine liberalization. The government, for example, still enforced interest rate "guidelines" through the 2000s. Still, China now has a set of large banks, each with an increasingly sophisticated concentration of human capital. Should the state privatize these banks, they may well be up to the challenge.

Changes are also taking place in China's bond markets. These were long overwhelmingly markets for trading bonds floated by the People's Bank of China, interbank CDs, and central and subnational government bonds. In 2009, corporate bonds had less than a $10 \%$ share. However, by 2015 , this had

\footnotetext{
${ }^{24}$ However, large scale lending by non-banks precipitated South Korea's "curb market lending" crisis, a major interruption in its financial development under General Park Chung-hee.

${ }^{25}$ Aayagari et al. (2017) using a survey of 2400 manufacturing and service firms in 2002 in 18 cities spread across the Coastal, Central, Northeast, Northwest and Southwest regions to show that bank financing is robustly and positively correlated with sales growth, profit reinvestment and productivity after controlling for firm size (dummies indicating a firm's status as microscopic, small, medium, large, and very large) and age (dummies indicating young, mid-age and old).
} 
grown to $25 \% .{ }^{26}$ China thus also has a functioning bond market that is providing capital to corporations, and could provide debt financing to private-sector firms or privatized state-owned enterprises should reforms advance.

Private enterprise is most apparent in the small and medium-sized firm sector. Revisions in 2006 to the Company Law reduced the minimum capital thresholds for limited liability firms to $¥ 5$ Million for listed firms and only $¥ 30,000$ for unlisted private-sector firms. The number of registered private enterprises expanded from 443,000 in 1996, when they accounted for less than a fifth of all enterprises, to $5,918,000$ in 2012, some 70\% of all firms (National Bureau of Statistics of China, 2013). Lardy (2014) shows that, in the cities, almost all the 250 million new jobs created since 1978 were in the private sector, broadly defined. Over 99\% of the urban labor force worked for the state in 1978; by 2011 only 18\% did. State-owned enterprises' share of exports has fallen from two-thirds in 1995 to 11\% in 2012. The small and medium-sized enterprise sector has served as a hothouse for developing entrepreneurial talent. This too improves China's readiness for large firm privatizations and more complete liberalization.

To date, China has cut its own development path, and may well be allocating capital more efficiently than might be expected of such a state-dominated economy. This may follow from the Party shaping cadres' private career incentives to promote growth-enhancing investment by local governments and SOEs. State-owned banks have clearly favored lending to SOEs, but are increasingly lending to other firms, and may be developing credit evaluation and borrower monitoring capabilities. This may reflect the career incentives confronting cadres running state-owned banks, which balance bank financial performance and adherence to Party policy and thus encourage lending to credit-worthy firms, not just SOEs.

Reforms to date have erected much of the financial machinery China would need to improve allocation efficiency by more fully liberalizing its economy and launching a private sector-led growth phase. This bodes well for a relatively painless shift from its recent surge of investment-led growth to a more sustainable productivity-led growth, should China's leaders elect to pursue this path. Japan and South Korea ultimately did this, albeit as an absolute last resort when all other options were closed off. Or China's leaders may try to continue cutting a new path to high-income levels without compromising the

\footnotetext{
${ }^{26}$ Deutsche Bank: Investing in China's Bond Market, July 2015
} 
Leading Role of the Party and state control of the Commanding Heights of its economy. Entering such uncharted territory would be a very daring move.

\section{An East Asian Model of Financial and Economic Development?}

The successful development of Japan, South Korea and China suggests some common themes.

One commonality across all three countries is a profound weakening of traditional institutions entrenching extractive elites before the era of rapid development. Japan's traditional elite was disgraced and marginalized after the Meiji Restoration put down samurai rebellions, leaving its new leaders free to rebuild the country's institutions along Western lines with little resistance from entrenched elites. South Korea's traditional elite was largely destroyed under Japanese colonial rule, its colonial-era elite was largely marginalized after Japan's surrender, and most remaining capital assets were devastated during the Korean War. China's traditional elite lost legitimacy as dysfunctional policies imploded the Qing dynasty and then the Republic of China. Mao's ideological purges culminating in the Cultural Revolution largely finished the job. All three countries thus became institutional blank slates, in the sense that their feudal landowners, court noblemen, regional warlords, and other traditional extractive elites with vested interests in blocking reforms were marginalized or eliminated in advance (Acemoglu et al. 2002).

All three countries also boasted high levels of literacy early on. Meiji Japan was an unusually literate society. Syngman Rhee, though his crony capitalism did little to raise living standards, did leave South Korea with universal public education. China in the early years of its reforms, perhaps recoiling from the anti-education excesses of Mao's Cultural Revolution, gave priority to reopening and restoring its schools and universities. Like Meiji Japan in the 1870s, China in the 1980s began sending students abroad and inviting foreign educators and experts to its universities. The marginalization of extractive elites may have paved the way for better general education and openness to new ideas from abroad. Acemoglu et al. (2002, p. 1278) argue that 
"low levels of human capital may have been a primary mechanism through which extractive institutions delayed industrialization." In all three countries, extensive investment in education may also have helped mitigate problems that stunt legal and other institutional transplants elsewhere (Berkowitz et al. 2003).

A third theme common to all three countries is a state-directed drive to transplant state-of-theart foreign technology into the domestic economy. In Meiji Japan and reform-era China, stateowned enterprises served as the delivery mechanism. In Park Chunghee's South Korea, subsidies to privately-owned business groups charged with developing domestic heavy and chemicals industries appear to have played this role. In Japan and Korea, this phase of development was relatively brief because the cost to the state triggered severe financial crises. China has so far sustained its state-owned enterprises, but its post-1978 reforms have brought in Western technology and management approaches.

A fourth theme common across all three countries is the exposure of domestic firms to global competition. In Japan, "unequal treaties" severely limited Japan's scope for erecting trade barriers, exposing the domestic economy to the Victorian era of globalization. Japanese firms, forced to compete, became major global exporters by the end of the $19^{\text {th }}$ century. In South Korea, General Park kept accounts of firms' exports to accumulate foreign exchange reserves, necessary under the Bretton Woods system to finance strategically important imports, especially those needed for military preparedness. Park awarded the CEOs of successful exporters medals and honours, but more importantly, linked subsidies to export success. China's rapid growth phase also corresponded to an era of unprecedented, if incomplete, openness to global economic competition. Chinese firms, like their Japanese and Korean predecessors, became major exporters early on. Reallocating underemployed labor has made China a global manufacturing center. Some Chinese firms have become globally competitive, due in part to successful large-scale adoptions of state-of-the-art foreign technology as well as their increasingly well-educated labor forces.

A fifth theme common across countries is the full-fledged embrace of free-market economics 
only as a last resort of desperation. Japan privatized its SOEs in the 1880 s only after their ongoing losses had bankrupted the government, ruined its credit in London (then the global financial center), and precipitated a severe financial crisis in Japan. Burned by the political fallout from all this, Japan's politicians adopted laissez-faire economic policies for the next several decades. With the government refraining from interfering in the economy, corrupting politicians became a low-return investment for a few decades at least. In Korea, Park Chunghee's Heavy and Chemicals Industry Drive, though done via subsidies to privately owned firms rather than via SOEs, also bankrupted the country. Immediately before his assassination, Park had decided to end all subsidies. His successor, Chun Doo-hwan, assessing the magnitude of the fiscal disaster and forced to accede to the demands of multinational financial institutions, followed through. He ended subsidies to business and presided over a thoroughgoing liberalization of the economy. Park's military ethos apparently kept corruption low; and Chun's ending subsidies lowered the return to influencing politicians for a time. In both Japan and Korea, talented entrepreneurs were left to get on with getting rich and both economies began to grow rapidly. Bequeathed the failures of central planning, China has introduced formats of Western market institutions and liberalized its economy to an unprecedented extent. But, its reforms are quite incomplete. The state still exercises a pervasive role in capital allocation and governance, and continues to divert capital into its stable of state-owned enterprises. Corruption also remains an important concern, though a 2012 reform may have had real impact. The unleashing of free market forces seems important in that this forced firms to cut wasteful resource misallocation and improve efficiency (Lin, Morck, Yeung Zhao, 2016).

A sixth theme is that all three economies developed mechanisms for coordinating the development of firms in multiple industries, so that essential supplier and customer firms arose to fill in missing supply chain links where necessary. During this phase of development, firms necessary to other firms might sometimes have to operate at a loss or fail to exploit market power for the sake of firms in other sectors. In both Meiji Japan and South Korea, large highly diversified business groups arose to meet this challenge. The largest of Japan's zaibatsu and Korea's chaebol business groups approached or achieved "full set" diversification - that is, they each contained a firm in every significant industry in the economy. Because all the firms in each 
business group were controlled by the same ultimate controlling shareholder, member firms could be restrained from exploiting their market power against each other and could be coerced into subsidizing money-losing member firms with critical supply chain functions. Because each major group also contained a member firm in each industry, firms outside the group could not exercise market power against group member firms. Because the ultimate controlling shareholder's private wealth depended on the performance of the group as a whole, and the business groups were competing with each other at the consumer retail level, the business groups as collectives were forced to be efficient. China has retained state control over huge sectors of its economy - notably banking, communications, construction, energy, heavy industry infrastructure, mining, power and transportation. State planners might conceivably implement a successful state-led Big Push. State planners in Japan and South Korea had to abandon this approach after bankrupting their governments. China's state planners might be better, but high leverage and rising efficiency and employment in the non-state sector suggest that China may not be different.

A seventh theme is that all three economies developed large functional equity markets when rapid expansions took place. Japan's stock markets facilitated its 1880s mass privatization. Upand-running stock markets also let Japan's zaibatsu business groups and Koreas' chaebol business groups expand rapidly, raising equity financing to capitalize subsidiaries and then subsidiaries of subsidiaries, and then subsidiaries of subsidiaries' subsidiaries. The resulting pyramidal structures let each group expand by issuing shares, a far more risk-tolerant source of capital than bank loans. Business groups that relied on bank loans to expand proved financially delicate, and failed during economic downturns in cascading bankruptcies that brought down entire business groups. China's stock markets have corporatized the bulk of its SOEs, and may now be ready to handle large-scale share issues to public investors and thus to provide the risktolerant capital needed to capitalize new and expanding firms to fill in missing links in the economy.

An eighth theme is the importance of avoiding or counteracting elite capture. Many developing economies become mired in a Middle Income Trap (Rajan and Zingales 2003; Morck, Wolfenzon 
and Yeung 2005), where a first generation of business tycoons grown rich off rapid early stage industrialization seek to lock in their (or their heirs') dominant economic, social and political positions by blocking subsequent entrants. The issue here is transition. Economy spanning corporate governance structures - Japan's zaibatsu, Korea's chaebols in Korea, or China's state machinery - sweeping enough to mobilize investment to finance and coordination a Big Push (Ronsentein-Rodan 1943, Murphy et al. 1989) bring the economy only so far. Schumpeter (1911) argues prosperous free market economies are rendered stable in the long-run by the process of creative destruction. New innovative firms arise, destroying old non-innovative giants. Firms are unstable so that capitalism becomes stable. Functionally efficient capital allocation is critical to financing new innovative firms (Levine and King 1993). The Middle Income Trap prevents the transition to growth through creative destruction by blocking creative destruction. Development stalls or even reverses and the country stagnates - always developing but never developed.

Japan's zaibatsu families attained sweeping economic power by the 1920s, when Japan joined the ranks of high-income economies. The democratic institutions the reformers had transplanted into Japan provided a degree of protection against elite capture, but by the beginning of the $20^{\text {th }}$ century Japan's political parties were undoubtedly being influenced by the zaibatsu families (Kerbo and McKinstry 1995, p. 43). Ultimately, the elite families grown wealthy amid Japan's early-stage development were first subordinated to the military dictatorship in the 1930s and then deprived of their business empires by the American military government after Japan's defeat in World War II. The post-war era then saw a wave of initial public offerings capitalizing new firms, such as Sony and Honda, that would catapult Japan to global technological leadership.

Korea's chaebol families remain powerful both economically and politically. Their influence over government policies is highly controversial and resented by many South Koreans. Past reforms aimed at reducing the power of the chaebol families have been largely ineffective. However, increasingly shocking scandals culminating in 2017 with the arrest of Lee Jae-yong, controlling scion of the Samsung chaebol, in a bribery scandal that led to the impeachment, disgrace, and 
arrest of President Park Geun-hye, the daughter of General Park Chung-hee. Chaebol reform became the top issue in the election to replace her, but skepticism remained. ${ }^{27}$ Efficient resource allocation remains an issue. The chaebol may continue to appear "too powerful to fail" giving their member firms privileged access to debt financing, thereby distorting capital allocation away from other firms.

China's prolonged state-control could either accentuate or mitigate such problems. On the one hand, the Communist Party of China leadership now includes many "princelings", descendants of Mao-era communist revolutionary leaders, who some see becoming an elite with a vested interest in the status quo (Brown 2014). On the other hand, China's reforms to date may open a path forward that prevents a first generation business elite from attaining the sort of power the zaibatsu and chaebol families attained in Japan and South Korea. Business groups arise in early stage development because they substitute intragroup transaction for inter-firm transactions made costly or impossible by dysfunctional markets. Markets become dysfunctional if suppliers or customers can exert market power either directly, by setting monopolistic prices, or indirectly, for example by providing low-quality intermediate goods. If China's government bureaucrats oversee the establishment of enough firms in enough industries in enough locations connected by good enough transportation and communication infrastructure, and let those firms compete enough to keep prices competitive throughout all necessary supply chains, China might not need zaibatsu or chaebol. China's stock markets may be up to the challenge and conditions are also ripe for the privatization of the large state-owned banks and nonfinancial enterprises. This would necessitate the comprehensive corporatization and privatization of SOES, the unrestricted entry of private sector firms, and rules and regulations that run predictably and without selective Party intervention.

China's leaders confront a dilemma. Accelerating the pace of reforms risks short-run volatility, for which officials would not want to be blameable. But, slow-paced reforms risk strengthening vested interests seeking to preserve the status quo as public sector and SOE debts accumulate.

\footnotetext{
${ }^{27}$ See e.g. "Chaebol reform at forefront of South Korea presidential campaign - again" by Hyunjoo Jin, Se Young Lee and Nichola Saminather. Reuters March 27, 2017.
} 
China might then become a middle-income trap economy, its pace of development slowed to preserve the economic and political power of its entrenched elites. Or, China may sacrifice fiscal prudence to hasten further rapid development without allowing the sort of free market competition and creative destruction that might threaten its elites. Such a path, in our opinion, is hard to sustain, especially with its aging population and increasingly tight resource constraints. The path ultimately forced the state to undertake comprehensive privatization and liberalization in Meiji Japan and comprehensive liberalization (privatizations having occurred earlier) in 1980s South Korea.

Comprehensive free market reforms were an absolute last resort in both Japan and Korea. Moreover, China has yet to experience a financial crisis as severe as those that ended statedirected development and unleashed free markets in Japan and Korea. If such a crisis ensues, China's leaders might likewise have no option but privatization and liberalization if it is to avoid ensnarement in a Middle Income Trap of political rent-seeking. Or, China may find its own path, perhaps a currently uncharted gradual ascent into the ranks of high-income economies. 


\section{References}

Acemoglu, Daron, Simon Johnson, James A. Robinson. 2002. Reversal of Fortune: Geography and Institutions in the Making of the Modern World Income Distribution. Quarterly Journal of Economics 117(4)1231-1294.

Albuquerue, Rui and Neng Wang. 2008. Agency conflicts, investment, and asset pricing. Journal of Finance 63(1)140.

Allen, F. and Gale, D. (1999) Diversity of opinion and financing of new technologies. Journal of Financial Intermediation 8: 68-89.

Allen, Franklin, Hun QJ Qian, Susan Chenyu Shan, and Julie Lei, Zhu. 2015. Explaining the Disconnection between China's Economic Growth and Stock Market Performance,. Memeo

Allen, Franklin, Jun QJ Qian, Chenying Zhang and Mengxin Zhao. 2012. China's Financial System: Opportunities and Challenges. In Fan and Morck, eds. Nov Capitalizing China, U of Chicago Press

Allen, Franklin, Jun QJ Qian, Meijun Qian. 2005. Law, Finance and Economic Growth in China, Journal of financial economics 77(1)57-116

Allen, William and Han Shen, 2012. “Assessing China's Top-down Securities Markets," In Fan and Morck, eds. Nov Capitalizing China, $U$ of Chicago Press

Almeida, Heitor; Kim, Chang-Soo; Kim, Hwanki Brian. 2015. Internal Capital Markets in Business Groups: Evidence from the Asian Financial Crisis. Journal of Finance 70(6)2539.

Almeida, Heitor; Park, Sang Yong; Subrahmanyam, Marti G; Wolfenzon, Daniel. 2011. The structure and formation of business groups: Evidence from Korean chaebols. Journal of Financial Economics 99(2)447.

Amiti, Mary; Weinstein, David E. 2011. Exports and Financial Shocks. Quarterly Journal of Economics 126(4)1841.

Amsden, Alice. 1991. Diffusion of Development: The Late-Industrializing Model and Greater East Asia. American Economic Review 81(2)282.

Aoki, Masahiko \& H. Patrick. 1994. The Japanese Main Bank System: Its Relevance for Developing and Transforming Economies. Oxford University Press

Aoki, Masahiko, Gregory Jackson \& Hideki Miyajima. 2007. Corporate Governance in Japan: Institutional Change and Organizational Diversity. Oxford University Press

Aoki, Masahiko, Gregory Jackson \& Hideki Miyajima. 2007. Corporate Governance in Japan: Institutional Change and Organizational Diversity. Oxford University Press

Aoki, Masahiko. 1988. Information, Incentives, and Bargaining in the Japanese Economy. Cambridge University Press, Cambridge.

Arikawa, Yasuhiro, and Yosuke Mitsusada. 2011. The adoption of poison pills and managerial entrenchment: Evidence from Japan. Japan and the World Economy 23(1)63-77.

Ayyagari Meghana, Asli Demirgilc, and Vojislav Maksimovic. 2017. Formal versus Informal Finance: Evidence from China," World Bank Policy Research Working Paper 4465

Azariadis, Costas; Drazen, Allan. 1990. Threshold Externalities in Economic Development. Quarterly Journal of Economics 105(2)501.

Bae, Gil S; Cheon, Youngsoon S; Jun-koo, Kang. 2008. Intragroup Propping: Evidence from the Stock-Price Effects of Earnings Announcements by Korean Business Groups. Review of Financial Studies 21(5)2015-2060.

Bae, Kee-Hong Bae; Jun-Koo, Kang; Chan-Woo, Lim. 2002. The value of durable bank relationships: Evidence from Korean banking shocks. Journal of Financial Economics 64.2 (May 2002): 181-214.

Baek, Jae-Seung, Jun-Koo Kang \& Inmoo Lee. 2006. Business Groups and Tunneling: Evidence from Private Securities Offerings by Korean Chaebols. Journal of Finance 61(5)2415-2449.

Barro, Robert J and Xavier Sala-i-Martin. 1978. Unanticipated Money, Output, and the Price Level in the United States. Journal of Political Economy 86(4)549- 58.

Barry Naughton. 2007. The Chinese Economy, Transition and Growth (MIT Press, 2007).

Beason, Richard and Dennis Patrick Patterson. 2004. The Japan That Never Was: Explaining the Rise and Decline of a Misunderstood Country. Albany: State University of New York Press.

Beason, Richard and D. E. Weinstein. 1996. "Growth, Economies of Scale, and Targeting in Japan (1955-1990)." Review of Economics and Statistics, 78(2), 286-95.

Beck, Thorsten, and Ross Levine. "Stock markets, banks, and growth: Panel evidence." Journal of Banking \& Finance 28.3 (2004): 423-442.

Beck, Thorsten, Asli Demirgüç-Kunt, and Ross Levine.2003. Law, endowments, and finance." Journal of Financial 
Economics 70(2)137-181.

Bee Yan Aw; Chung, Sukkyun; Roberts, Mark J. 2003. Productivity, output, and failure: a comparison of Taiwanese and Korean manufacturers. Economic Journal 113(491)F485-F510.

Berkowitz, Daniel, Katharina Pistor, and Jean-Francois Richard. 2003. The transplant effect. American Journal of Comparative Law 51(1)163-203.

Berkowitz, Daniel, Hong Ma, and Shuichiro Nishioka. 2016. Recasting the Iron Rice Bowl: The Reform of China's State Owned Enterprises." Review of Economics and Statistics forthcoming.

Bjuggren, Per-Olof, and Johanna Palmberg. "The impact of vote differentiation on investment performance in listed family firms." Family Business Review 23.4 (2010): 327-340.

Black, Bernard; Kim, Woochan.2012. The effect of board structure on firm value: A multiple identification strategies approach using Korean data. Journal of Financial Economics 104(1)203.

Bolt, J. and J. L. van Zanden. 2014. The Maddison Project: collaborative research on historical national accounts. Economic History Review 67(3)627-651.

Bolt, Jutta, Marcel Timmer and Jan Luiten van Zanden. 2014. GDP per capita since 1820, in Jan Luiten van Zanden, et al. eds. How Was Life? Global Well-being since 1820, OECD Publishing

Boot, Max. 2006. War Made New: Weapons, Warriors, and the Making of the Modern World. Penguin.

Boyd, J.H. and Smith, B.D. (1998) The evolution of debt and equity markets in economic development. Economic Theory 12: 519-560.

Brandt, L., Rawski, T. and Sutton, J. 2008. China's industrial development. in L. Brandt and T. Rawski eds. China's Great Economic Transformation, Cambridge University Press, Cambridge, pp. 569-632

Brandt, Loren, Debin Ma, and Thomas G. Rawski. 2014. From Divergence to Convergence: Reevaluating the History Behind China's Economic Boom, Journal of Economic Literature 2014, 52(1), 45-123

Bransetter, Lee. 2008. China's embrace of globalization, in Brandt, Loren; Rawski, G. Thomas, China's Great Transformation, Cambridge, UK: Cambridge University Press, p. 655

Brown, James R., Gustav Martinsson, and Bruce C. Petersen. "Law, stock markets, and innovation." The Journal of Finance 68.4 (2013): 1517-1549.

Brown, Kerry. 2014. The New Emperors: Power and the Princelings in China. I.B.Tauris.

Brunnermeier, Markus K., Michael Sockin and Wei Xiong. 2017. China's Gradualistic Economic Approach and Financial Markets. American Economic Review, (May): 608-613.

Buruma, Ian. 2003. Inventing Japan: 1853-1964. Random House.

Byun, Hae-Young; Choi, Sunhwa; Hwang, Lee-Seok; Kim, Robert G. 2013. Business group affiliation, ownership structure, and the cost of debt. Journal of Corporate Finance 23(Dec.)311.

Campbell, Colin D; Tullock, Gordon. 1957. Some Little-Understood Aspects of Korea's Monetary and Fiscal Systems. American Economic Review 47(3)336.

Caprio, G. Jr., Levine, R. (2002). "Corporate governance in finance: Concepts and international observations". In: Litan, R.E., Pomerleano, M., Sundararajan, V. (Eds.), Financial Sector Governance: The Roles of the Public and Private Sectors. The Brookings Institution, Washington, DC, pp. 17-50.

Caprio, Gerard, Luc Laeven, and Ross Levine. "Governance and bank valuation." Journal of Financial Intermediation 16.4 (2007): 584-617.

Carpenter, Jennifer N., Fangzhou Lu, and Robert F. Whitelaw. 2014. The Real Value of China's Stock Market, Stern, NYU, mimeo.

Castro, Rui; Clementi, Gian Luca; MacDonald, Glenn. 2004. Investor protection, optimal incentives, and economic growth. Quarterly Journal of Economics 119(3)1131-1175.

Chandra, Nirmal Kumar. 1987. Education in China: from the Cultural Revolution to Four Modernizaitons Economic and Political Weekly 22(19/21)121-136

Chang, Parris H. 1974. The Cultural Revolution and Chinese Higher Education: Change and Controversy, The Journal of General Education 26(3)187-194

Chapin, Emerson. 1969. Success Story in South Korea. Foreign Affairs 47(3)560-574.

Chiu, B. and Lewis, M. 2006. Reforming China's State-Owned Enterprises and Banks, Edward Elgar Publishing Ltd., Cheltenham

Cho, Yoon-Je and Joon-Kyung Kim. 1997. Credit Policies and the Industrialization of Korea. Korea Development Institute.

Choe, Hyuk; Bong-Chan Kho; René M. Stulz. 2005. Do Domestic Investors Have an Edge? The Trading Experience of 
Foreign Investors in Korea. Review of Financial Studies 18(3)795.

Choe, Hyuk; Bong-Chan Kho; Stulz, Rene M. 1999. Do foreign investors destabilize stock markets? The Korean experience in 1997. Journal of Financial Economics 54(2)227-264.

Choi, Jongmoo Jay; Hiraki, Takato; Landi, James A. 2014. The value of multinationality and business group for Japanese firms. Journal of Corporate Finance 29 (Dec)88.

Choi, Jongmoo Jay; Park, Sae Woon; Too, Sean Sehyun. 2007. The Value of Outside Directors: Evidence from Corporate Governance Reform in Korea. Journal of Financial and Quantitative Analysis 42(4)941.

Collins, Susan M. 1990. Lessons From Korean Economic Growth. American Economic Review 80(2)104.

Cooney, John W, Jr; Hideaki Kiyoshi Kato; Schallheim, James S. 2003. Underwriter Certification and Japanese Seasoned Equity Issues. Review of Financial Studies 16.3 (Autumn 2003): 949-982.

Davies, K. 2013. China Investment Policy: An Update, OECD Working Papers on International Investment, 2013/01, OECD Publishing.

Demirguc-Kunt, A. and Maksimovic, V. (2002) Funding growth in bank-based and market-based financial systems: evidence from firm-level data. Journal of Financial Economics 65: 337-363.

Deng Yongheng, Wu Jing, Randall Morck and Bernard Yeung. 2015. China's Pseudo Monetary Policy. Review of Finance 19, 55-93.

Domar, Evsey D. 1946. Capital expansion, rate of growth, and employment. Econometrica, 137-147.

Easterly, William and Ross Levine. 1997. Africa's growth tragedy: policies and ethnic divisions. Quarterly Journal of Economics 112 1203-1250.

Easterly, William, and Ross Levine. "The European origins of economic development." Journal of Economic Growth 21.3 (2016): 225-257.

Easterly, William. 2006. The Big Push déjà vu. Journal of Economic Literature 44(1)96-105.

Ebenstein, Avraham, Maoyong Fan, Michael Greenstone, Guojun He and Peng Yin. 2015. Growth, Pollution and Life Expectancy: China from 1991-2012, American Economic Review, (May) 226-231.

Ebenstein, Avraham. 2012. The Consequences of Industrialization: Evidence from Water Pollution and Digestive Cancer in China, the Review of Economics and Statistics, (Feb): 186

Elliott, Douglas J. and Kai Yan. 2013. The Chinese Financial System, the John L. Thornton China Center at Brookings

Elliott, Mark C., (2001) The Manchu Way: The Eight Banners and Ethnic Identity in Late Imperial China, Stanford University Press, ISBN 978-0-8047-4684-7. Fan, Gang, and Nicolas C. Hope. 2013. The role of State-Owned Enterprises in the Chinese Economy,

Fairbank, John K., Alexander Eckstein, and L. S. Yang. 1960. Economic change in early modern China: an analytic framework. Economic Development and Cultural Change 9(1)1-26.

Fan, Joseph, Randall Morck, and Bernard Yeung. 2012. Translating Market Socialism with Chinese Characteristics into Sustained Prosperity. In Joseph Fan and Randall Morck, eds. Capitalizing China. University of Chicago Press.

Feenstra, Robert C; Markusen, James R; Zeile, William. 1992. Accounting for Growth with New Inputs: Theory and Evidence. American Economic Review 82(2)415.

Flath, David. 1993. Shareholding in the Keiretsu, Japan's financial groups. Review of Economics and Statistics $75(2) 249$.

Fohlin, Caroline. 2005. The history of corporate ownership and control in Germany. In Randall Morck, ed. A history of corporate governance around the world: Family business groups to professional managers. University of Chicago Press, 223-282.

Franks, Julian, Colin Mayer, and Hannes F. Wagner. "The Survival of the Weakest: Flourishing Family Firms in Germany." Journal of Applied Corporate Finance 27.4 (2015): 27-35.

Franks, Julian, Colin Mayer, and Hideaki Miyajima. "The ownership of Japanese corporations in the 20th century." Review of Financial Studies 27.9 (2014): 2580-2625.

Franks, Julian; Mayer, Colin; Miyajima, Hideaki. 2014. The Ownership of Japanese Corporations in the 20th Century. Review of Financial Studies 27(9) 2580.

Gan, Jie. 2007. The Real Effects of Asset Market Bubbles: Loan- and Firm-Level Evidence of a Lending Channel. Review of Financial Studies 20(6)1941.

Giannetti, Mariassunta, Guanmin Liao and Xiaoyun Yu. 2015. The Brain Gain of Corporate Boards: Evidence from China. Journal of Finance, 1629 
Gompers, Paul Alan, and Joshua Lerner. The venture capital cycle. MIT press, 2004.

Gordon, Roger H. and Wei Li, 2012, "Provincial and Local Governments in China: Fiscal Institutions and Government Behavior," In Fan and Morck, eds. Nov Capitalizing China, U of Chicago Press

Gormley, Todd A; Johnson, Simon; Rhee, Changyong. 2015. Ending "Too Big To Fail": Government Promises Versus Investor Perceptions. Review of Finance 19(2)491.

Goto, Akira. 1982. Business Groups in a Market Economy. European Economic Review 19, 53-70.

Grossman, Sanford and Oliver Hart. 1986. The costs and benefits of ownership: A theory of Vertical and Lateral Integration. Journal of Political Economy 94, 691-719

Haber, S.H. 2004. Political competition and economic growth: Lessons from the political economy of bank regulation in the United States and Mexico. Mimeo. Stanford University.

Haber, S.H. 2005. "Mexico's experiment with bank privatization and liberalization, 1991-2004". Journal of Banking and Finance.

Haggard, Stephan, Byung-kook Kim, and Chung-in Moon. 1991. The transition to export-led growth in South Korea: 1954-1966. The Journal of Asian Studies 50(4)850-873.

Haggard, Stephan, David Kang, and Chung-In Moon. 1997. Japanese colonialism and Korean development: A critique. World Development 25(6)867-881.

Haggard, Stephan, Wonhyuk Lim, and Euysung Kim, eds. Economic crisis and corporate restructuring in Korea: Reforming the Chaebol. Cambridge University Press, 2003.

Hanazaki, Masuharu and Akiyoshi Horiuchi. 2000. "Is Japan's Financial System Efficient?" Oxford Review of Economic Policy 16(2), 61-73.

Hanazaki, Masuharu and Akiyoshi Horiuchi. 2001. "A Vacuum of Governance in the Japanese Bank Management." In H. Osano and T. Tachibanaki (eds.), Banking, Capital Markets and Corporate Governance. Palgrave, 133180.

Harrod, Roy. 1939. An Essay in Dynamic Theory. Economic Journal 49(193)14-33.

Hart, Oliver, and John Moore. "Property Rights and the Nature of the Firm." Journal of political economy 98.6 (1990): 1119-1158.

Hauser, Shmuel, and Beni Lauterbach. 2004. The value of voting rights to majority shareholders: Evidence from dual-class stock unifications. Review of Financial Studies 17(4)1167-1184.

Henrekson, Magnus \& Jakobsson, Ulf. 2003. The transformation of ownership policy and structure in Sweden: convergence towards the Anglo-Saxon model?" New Political Economy 8(1)73-102.

Hideaki Kiyoshi Kato; Lemmon, Michael; Luo, Mi; Schallheim, James. 2005. An empirical examination of the costs and benefits of executive stock options: Evidence from Japan. Journal of Financial Economics 78(2)435461.

Historical Materials of Shanghai qianzhuang (上海钱庄史料: Shanghai qianzhuang shi liao). 1961. Zhongguo Renmin Yinhang Shanghai fenghang, Jinrong Yanjiu Suo (Institute of Financial Studies, Shanghai Branch, People's Bank of China), ed.,1961, Shanghai (reprint, Shanghai, 1978)

Ho, Jun Seong. 2014. Monetary authority independence and stability in medieval Korea: The Koryŏ monetary system through four centuries of East Asian transformations, 918-1392. Financial History Review 21(3)259-280.

Hodder, James E; Tschoegl, Adrian E. 1985. Some Aspects of Japanese Corporate Finance. Journal of Financial and Quantitative Analysis; Seattle20.2 (Jun 1985): 173.

Hofstede, Geert, and Michael Harris Bond. 1988. The Confucius connection: From cultural roots to economic growth. Organizational Dynamics 16(4)5-21.

Högfeldt, Peter. 2005. The History and Politics of Corporate Ownership in Sweden. In Randall Morck ed., A History of Corporate Governance around the World. Family Business Groups to Professional Managers. University of Chicago Press.

Hoshi, Takeo and Anil Kashyap. 2001. Corporate Finance \& Governance in Japan: The Road to the Future. MIT Press.

Hoshi, Takeo, Anil Kashyap, and David Scharfstein. 1990. The role of banks in reducing the costs of financial distress in Japan. Journal of Financial Economics 27(1)67-88.

Hoshi, Takeo, Anil Kashyap, and David Scharfstein. 1991. Corporate structure, liquidity, and investment: Evidence from Japanese industrial groups. Quarterly Journal of Economics 106(1)33-60.

Hoshi, Takeo; Kashyap, Anil K. 2004. Japan's Financial Crisis and Economic Stagnation. Journal of Economic 
Perspectives 18(1)3-26.

Hsieh, Chang-Tai and Peter Klenow. 2009. Misallocation and Manufacturing TFP in China and India, Quarterly Journal of Economics 74(Nov.)1403-48.

Huang Jianhui. 1992. Shanxi piaohao shi. Taiyuan: Shanxi jingji chubanshe.

Huang, Yasheng. 2012. How did China Take Off? Journal of Economic Perspectives, 3,147-170.

Huybens, Elisabeth, and Bruce D. Smith. "Inflation, financial markets and long-run real activity." Journal of Monetary Economics 43.2 (1999): 283-315.

Jae-Seung Baek; Jun-Koo, Kang; Kyung Suh Park.2004. Corporate governance and firm value: evidence from the Korean financial crisis. Journal of Financial Economics 72(2)265-313.

Jeong, Kap-Young; Masson, Robert T. 1990. Market Structure, Entry, and Performance in Korea. Review of Economics and Statistics 72(3)455.

Jackson, Gregory. 2001. The Origins of Bank-based and Market Based Financial Systems in Japan, Germany and the United States. In Wolfgang Streeck and Kōzō Yamamura, eds. The Origins of Nonliberal Capitalism: Germany and Japan in Comparison. Cornell University Press.

Joh, Sung Wook.2003. Corporate governance and firm profitability: evidence from Korea before the economic crisis. Journal of Financial Economics 68(2)287-322.

Johnson, Chalmers. 1982. MITI and the Japanese Miracle: The growth of industrial policy 1925-1975. Stanford University Press.

Jun-Koo, Kang; Shivdasani, Anil; Yamada, Takeshi. 2000. The effect of bank relations on investment decisions: An investigation of Japanese takeover bids. Journal of Finance 55(5)2197-2218.

Kajima, Morinosuke. The emergence of Japan as a world power, 1895-1925. Tuttle Publishing, 1967.

Kandel, Eugene, Konstantin Kosenko, Randall Morck, and Yishay Yafeh. 2017. The great pyramids of America: A revised history of US business groups, corporate ownership and regulation, 1930-1950. National Bureau of Economic Research working paper 19691.

Kaplan, Steven and Bernadette Minton 1994. Appointments of outsiders to Japanese boards: Determinants and implications for managers. Journal of Financial Economics 36(2)225-258.

Karmel, Solomon. 2017. Research Notes: Emerging Securities Markets in China: Capitalism with Chinese Characteristics. In Michael Dillon, ed. Key Papers of Chinese Economic History since 1949, pp. 1253-1273. Koninklijke Brill: Leiden.

Kato, T. 1957. History of Banks in Japan (Honpo ginkoshiron), (in Japanese), University of Tokyo Press, Tokyo.

Kee-Hong Bae; Jun-Koo, Kang; Jin-Mo, Kim. 2002. Tunneling or value added? Evidence from mergers by Korean business groups. Journal of Finance 57(6)2695-2740.

Keller, Wolfgang, Ben Li and Carol Shiue. 2011. China's Foreign Trade: Perspectives From the Past 150 Years The World Economy, Wiley Blackwell, vol. 34(6)853-892.

Kerbo, R. and John McKinstry. 1995. Who Rules Japan? The Inner Circles of Economic and Political Power. Praeger.

Kim, Hyung-A. 2004. Korea's Development under Park Chung Hee. Routledge.

Kim, Jae-on and B. C. Koh. 1972. Electoral behavior and social development in South Korea: An aggregate data analysis of presidential elections. Journal of Politics 34(3)825-859.

Kim, Ryoonhee. 2017. Financial Weakness and Product Market Performance: Internal Capital Market Evidence. Journal of Financial and Quantitative Analysis 51(1)307.

King, R.G. and Ross Levine. 1993a. Finance and growth: Schumpeter might be right. Quarterly Journal of Economics 108: 717-737.

King, R.G. and Ross Levine. 1993b. Finance, entrepreneurship, and growth: theory and evidence. Journal of Monetary Economics 32: 513-542.

King, Robert G., and Ross Levine. 1994. Capital fundamentalism, economic development, and economic growth. Carnegie-Rochester Conference Series on Public Policy. Vol. 40. North-Holland.

Kohli, Atul. 1999. Where do high-growth political economies come from? The Japanese Lineage of Korea's Developmental State. In Merideth Woo-Cummings, ed. The Developmental State. Cornell University Press, c. 4.

Kornai, James. 1986. The soft budget constraint. Kyklos 39(1)3-30.

Kornicki, Peter Francis. 1998. The Book in Japan: A Cultural History from the Beginnings to the 19th Century (Handbook of Oriental Studies. Section 5: Japan). Brill.

Kung \& Lin. 2007. The Decline of Township-and-Village Enterprises in China's Economic Transition. World 
Development 35(4).

Kunt, Asli Demirguc and Ross Levine. 2001 Financial structure and economic growth: a cross-country comparison of banks, markets, and development. MIT Press.

Kuo, Ting-Yee and Kwang-Ching Liu. 1978. Self-strengthening: the Pursuit of Western Technology. In John K. Fairbank, ed. Cambridge History of China, Vol 10: Late Chi'ing 1800-1911: Part 1, e 491-542, Cambridge: Cambridge University Press.

Kutsuna, Kenji. 2004. Why Does Book Building Drive Out Auction Methods of IPO Issuance? Evidence from Japan. Review of Financial Studies 17(4)1129-1166.

Kutsuna, Kenji; Smith, Janet Kiholm; Smith, Richard L. 2009. Public Information, IPO Price Formation, and Long-Run Returns: Japanese Evidence. Journal of Finance 64(1)505.

Kwon, Jene K; Paik, Hoon. 1995. Factor price distortions, resource allocation, and growth: A computable general equilibrium analysis. Review of Economics and Statistics 77(4)664.

La Porta, R., Lopez-de-Silanes, F., Zamarripa, G. (2003). "Related lending". Quarterly Journal of Economics.

La Porta, Rafael, Florencio Lopez-de-Silanes, and Andrei Shleifer. "The economic consequences of legal origins." Journal of economic literature 46.2 (2008): 285-332.

La Porta, Rafael, Florencio Lopez-de-Silanes, and Andrei Shleifer. 2002. Government ownership of banks. Journal of Finance 57()1)265-301.

Laeven, L. (2001). "Insider lending: The case of Russia". Journal of Comparative Economics 29, 207-229.

Laeven, L., Levine, R. (2005). "Is there a diversification discount in financial conglomerates?". Journal of Financial Economics.

Laeven, Luc, and Ross Levine. 2009. Bank governance, regulation and risk taking." Journal of financial economics 93(2)259-275.

Lardy, Nichalas. 2014. Markets over Mao: The Rise of Private Business in China. Peterson Institute of International Economics.

Lardy, Nicholas. 2003.Trade Liberalization and Its Role in Chinese Economic Growth IIE - Paper prepared for an International Monetary Fund and National Council of Applied Economic Research Conference A Tale of Two Giants: India's and China's Experience with Reform and Growth New Delhi, November 14-16

Larsson, Mats \& Tom Petersson. 2017. Tradition and renewal - business groups in Sweden. In Asli Colpan and Takashi Hikino, eds. Diversified Business Groups in the West: History and Theory, forthcoming.

Lawrence J. Lau, Yingyi Qian, Gerard Roland. 2000. An Interpretation of China's Dual-Track Approach to Transition. Journal of Political Economy (2000): 120-143.

Levine, R. (2002) Bank-based or market-based financial systems: which is better? Journal of Financial Intermediation 11: 398-428.

Levine, R. and Zervos, S. (1998) Stock markets, banks, and economic growth. American Economic Review 88: 537558.

Levine, Ross. "Financial development and economic growth: views and agenda." Journal of economic literature 35.2 (1997): 688-726.

Lewis, W. Arthur. 1954. Economic development with unlimited supplies of labour. Manchester School 22(2)139191.

Li, David D; Li, Shan. 1996. A theory of corporate scope and financial structure. Journal of Finance 51(2)691.

$\mathrm{Li}$, Hongbin and Li-an Zhou. 2005. Political Turnover and Economic Performance: The Incentive Role of Personnel Control in China, Journal of Public Economics 89(9/10)1743-72.

Li, Zhaohua, Takeshi Yamada. 2015. Political and Economic Incentives of Government in Partial Privatization. Journal of Corporate Finance (Jun) 169.

Lim, Wonhyuk, and Joon-Ho Hahm. 2006. Turning a Crisis into an Opportunity: The Political Economy of Korea's Financial Sector Reform. From Crisis to Opportunity: Financial Globalization and East Asian Capitalism (2006): 85-121.

Lim, Wonhyuk. 2000. The Origin and Evolution of the Korean Economic System. Seoul: Korea Development Institute Press.

Lim, Wonhyuk. 2003 The Emergence of the Chaebol and the Origins of the Chaebol Problem. In Wonhyuk Lim, Stephan Haggard, and Euysung Kim, eds. Economic crisis and corporate restructuring in Korea: Reforming the chaebol, 35-52.

Lim, Wonhyuk. 2012. Chaebol and industrial policy in Korea. Asian Economic Policy Review 7(1)69-86. 
Lin Chen, Randall Morck, Bernard Yeung and Xiaofeng Zhao, (2016), Anti-Corruption Reforms and Shareholder Valuations: Event Study Evidence from China," NBER Working Paper 22001, Feb 2016.

Love, I. (2003). "Financial development and financing constraint: International evidence from the structural investment model". Review of Financial Studies 16, 765-791.

Lü, Xiaobo. 2000. Cadres and Corruption: The Organizational Involution of the Chinese Communist Party. Stanford University Press.

Luintel, Kul B., Mosahid Khan, Philip Arestis, and Konstantinos Theodoridis. "Financial structure and economic growth." Journal of Development Economics 86, no. 1 (2008): 181-200.

McGregor, Richard. 2010. The Party: The Secret World of China's Communist Rulers. Penguin.

Mehrotra, Vikas, Randall Morck, Jungwook Shim, and Yupana Wiwattanakantang. 2013. Adoptive Expectations: Rising Sons in Japanese family firms. Journal of Financial Economics 108(3)840-854.

Mehrotra, Vikas; van Schaik, Dimitri; Spronk, Jaap; Steenbeek, Onno. 2011. A Creditor-Focused Corporate Governance: Evidence from Mergers and Acquisitions in Japan. Journal of Financial and Quantitative Analysis 46(4)1051.

Meissner, Christopher M. \& John P. Tang. 2017. Upstart Industrialization and Exports, Japan 1880-1910. NBER wp 23481.

Minetti, Raoul; Yun, Sung-Guan. 2015. Institutions, Bailout Policies, and Bank Loan Contracting: Evidence from Korean Chaebols. Review of Finance 19(6)2223.

Mitchener, Kris James \& Ohnuki, Mari, 2009. Institutions, Competition, and Capital Market Integration in Japan. Journal of Economic History 69(01)138-171,

Miyajima, Hideaki. 2004. Economic History of Industrial Policy and Corporate Governance: Micro Analysis of Japanese Industrial Development. Tokyo

Mo, Jongryn, and Barry R. Weingast. 2013. Korean political and economic development: crisis, security, and institutional rebalancing. Harvard University Asia Center.

Morck, Randall. 2005. How to eliminate pyramidal business groups: the double taxation of intercorporate dividends and other incisive uses of tax policy. Tax policy and the economy 19(1)135-179.

Morck, R. and M. Nakamura. 1999. "Banks and Corporate Control in Japan." Journal of Finance, 54(1), 319-39.

Morck, R. and M. Nakamura. 2007. Business Groups and the Big Push: Meiji Japan's Mass Privatization and Subsequent Growth. Enterprise \& Society, 8(3), 543-601.

Morck, R. K. and M. Nakamura. 2005. A Frog in a Well Knows Nothing of the Ocean a History of Corporate Ownership in Japan. In Randall Morck, ed. History of Corporate Governance around the World, University of Chicago Press, pp. 367-465.

Morck, R.; M. Nakamura and A. Shivdasani. 2000. Banks, Ownership Structure, and Firm Value in Japan. Journal of Business, 73(4), 539-67.

Morck, Randall, Daniel Wolfenzon and Bernard Yeung, 2005. Corporate Governance, Economic Entrenchment and Growth. Journal of Economics Literature 43(3)657-722.

Morck, Randall, M. Deniz Yavuz, and Bernard Yeung. 2011. Banking system control, capital allocation, and economy performance. Journal of Financial Economics 100.2 264-283.

Morck, Randall, M. Deniz Yavuz, and Bernard Yeung. 2011. Banking system control, capital allocation, and economy performance." Journal of Financial Economics 100( 2)264-283.

Morck, Randall, and Fan Yang. 2011. The Shanxi Banks: The Rise and Fall of the Rishengchang Bank Model Limiting Shareholder Influence to Attract Capital. In Origins of Shareholder Advocacy, pp. 187-212. Palgrave Macmillan.

Morck, Randall and Bernard Yeung. 2016. China in Asia, China Economic Review, (40) 2016, 297-308.

Morikawa, Hidemasa. 1992. Zaibatsu: the rise and fall of family enterprise groups in Japan, University of Tokyo Press, Tokyo.

Morris-Suzuki, Tessa, and Takurō Seiyama, eds. 1989. Japanese capitalism since 1945: critical perspectives. ME Sharpe.

Murphy, K. M.; A. Shleifer and R. W. Vishny. 1989. Industrialization and the Big Push. Journal of Political Economy, 97(5), 1003-26.

Noguchi, Yukio. 1998. The 1940 system: Japan under the wartime economy. American Economic Review 88(2)404407.

Norton, Roger D. Planning with Facts: The Case of Korea. American Economic Review 60(2)59. 
Okazaki, Tetsuji. 1994. "The Japanese Firm under the Wartime planned Economy." In Masashiko Aoki and Ronald Dore (eds.), The Japanese Firm - Sources of Competitive Strength. Oxford University Press.

Okazaki, Tetsuji; Sawada, Michiru. 2007. Effects of a bank consolidation promotion policy: evaluating the 1927 Bank Law in Japan. Financial History Review 14.1 (Apr 2007): 29-61.

Olson, Mancur. 1986. Rapid Growth as a Destablizing Force. Journal of Economic History 23(4)529-52.

Park, Seung-Rok; Kwon, Jene K. 1995. Rapid economic growth with increasing returns to scale and little or no productivity growth. Review of Economics and Statistics 77(2)332.

Park, Sooyoung. 2009. Analysis of Saemaul Undong: a Korean rural development programme in the 1970s. AsiaPacific Development Journal 16(2)113.

Park, Yung Chul. 1990. Development Lessons from Asia: The Role of Government In South Korea. American Economic Review 80(2)118.

Peek, Joe \& Eric Rosengren 2005. Unnatural Selection: Perverse incentives \& the misallocation of credit in Japan. American Economic Review 95, 1144-66.

Peek, Joe; Rosengren, Eric S. 2005. Unnatural Selection: Perverse Incentives and the Misallocation of Credit in Japan. American Economic Review 95(4)1144-1166.

Prowse, Stephen D. 1990. Institutional Investment Patterns and Corporate Financial Behavior in the United States and Japan. Journal of Financial Economics 27(1)43.

Qian, Yangyi. 2000. The process of China's market transitions: evolutionary, historical and comparative perspective, Journal of Institutional and Theoretical Economics, 156, 151-171

Qian, Yingyi. 2003. How Reform Worked in China. In Dani Rodik, ed. In Search for Prosperity Analytic Narratives on Economic Growth. New Jessy: Princeton University Press, 143-168.

Rajan, R.G. and Zingales, L. (1998) Financial dependence and growth. American Economic Review 88: 559-586.

Rajan, Raghuram and Luigi Zingales. 2003. Saving capitalism from the capitalists. New York: Crown Business, 2003.

Rajan, Raghuram and Luigi Zingales. 2003. The great reversals: the politics of financial development in the twentieth century. Journal of financial economics 69(1)5-50.

Ramazani, Reza M; Maskus, Keith E. 1993. A test of the factor endowments model of trade in a rapidly industrializing country: The case of Korea. Review of Economics and Statistics 75(3)568.

Reischauer, Edwin O. 1988. The Japanese Today: Change and Continuity. Harvard University Press, Cambridge: MA. Rosovsky, Henry. 1961. Capital Formation in Japan: 1868-1940. Free Press of Glencoe.

Schrecker, John E. (2004) The Chinese Revolution in Historical Perspective, Greenwood Publishing Group.

Seth, Michael J. 2002. Education fever: Society, politics, and the pursuit of schooling in South Korea. University of Hawaii Press.

Sheard, Paul. 1991. The economics of interlocking shareholding in Japan. Richerche Economiche 45, 421448.

Sheard, Paul. 1994. Interlocking Shareholdings and Corporate Governance. In Masahiko Aoki and Ronald Dore (eds.) The Japanese Firm: Sources of Competitive Strength. Oxford University Press.

Sussman, N., \& Yafeh, Y. 2000. Institutions, reforms, and country risk: Lessons from Japanese government debt in the Meiji era. Journal of Economic History 60(2)42-467.

Takahashi, Hidenori. 2015. Dynamics of bank relationships in entrepreneurial finance. Journal of Corporate Finance 34 (Oct) 23.

Teranishi, Juro. 2005. Evolution of the Economic System in Japan. Cheltenham: Edward Elgar.

Triade, Victor. 2005. The Big Push, Industrialization and International Trade: The Role of Exports. Journal of Development Economics 76(Oct.)22-48.

Uchida, Hirofumi; Nakagawa, Ryuichi. 2007. Herd behavior in the Japanese loan market: Evidence from bank panel data. Journal of Financial Intermediation 16(4)555-583.

Wang, Shaoguang. 2006. Openness and Inequality: The case of China. In Lowell Dittmer and Guoli Liu, eds. China's Deep Reform: Domestic Politics in Transition. Rowman \& Littlefield, 285-302.

Weber, Max. 1915. Konfuzianismus und Taoismus. Tübingen, JCB Mohr.

Weinstein, David E., and Yishay Yafeh. "On the costs of a bank-centered financial system: Evidence from the changing main bank relations in Japan." Journal of Finance 53.2 (1998): 635-672.

Weinstein, David E; Yafeh, Yishay. 1998. On the costs of a bank-centered financial system: Evidence from the changing main bank relations in Japan. Journal of Finance 53.2 (Apr 1998): 635-672.

Weiss, Tim and Klaus Weber. 2017. Globalization in action: Templates, tensions and strategies of action In Kenyan technology entrepreneurship. Northwestern University Working paper. 
Woo, Jung-en. 1991. Race to the Swift: State and Finance in Korean Industrialization. Columbia University Press. World Bank, 1992. China: Implications and Option of Urban Housing Reforms. Washington DC.

Wu Jinglian and Renwei Zhao. 1987. The Dual Pricing System in China's Industry, Journal of Comparative Economics, 11(3)309-318

Wu, Jing, Yongheng Deng, Jun Huang, Randall Morck and Bernard Yeung, 2014. Incentives and Outcomes: China's Environmental Policy. Capitalism and Society 9(1)2.

Xie, Yu and Zhou, Xiang. 2014. Income Inequality in Today's China. Proceedings of the National Academy of Sciences 111(19)6928-33.

Xu, Chenggang. 2011. The Fundamental Institutions of China's Reforms and Development, the Journal Economic Literature (Dec.)1076-1151

Yafeh, Y. \& Khanna, T. 2007. Business Groups in Emerging Markets: Paragons or Parasites? Journal of Economic Literature 45(2)331-373

Yafeh, Y. \& Khanna, T. 2005. Business Groups and Risk Sharing around the World. Journal of Business 78(1)301340.

Yang, Yung Y; Hwang, Min. 1994. Price behavior in Korean manufacturing. Review of Economics and Statistics 76.3 (Aug 1994): 461.

Yasuda, Ayako. 2007. Bank relationships and underwriter competition: Evidence from Japan. Journal of Financial Economics 86(2)369.

Young, Alwyn. 1995. The tyranny of numbers: Confronting the statistical realities of the East Asian growth experience. Quarterly Journal of Economics 110(3)641.

Zheng Siqi and Matthew Kahn. 2013. Understanding China's Urban Pollution Dynamics, Journal of Economic Literature (Sept.)731-772.

Zheng, Siqi and Matthew Kahn. 2017. A New Era of Pollution Progress in Urban China? Journal of Economic Perspectives, Winter, 71-92

Zhu Ning. 2016. The Guaranteed Bubble. Feb 2016

Zweig, David and Stanley Rosen. 2003. How China trained a new generation abroad. Science and Development Network 22/05/03. 